\title{
Effect of transcription inhibition and generation of suppressive viral non-coding RNAs
}

Daniel O. Pinto ${ }^{1}$, Tristan A. Scott ${ }^{2}$, Catherine DeMarino ${ }^{1}$, Michelle L. Pleet ${ }^{1}$, Thy T. Vo ${ }^{1}$, Mohammed Saifuddin ${ }^{1}$, Dmytro Kovalskyy ${ }^{3}$, James Erickson ${ }^{1}$, Maria Cowen ${ }^{1}$, Robert A. Barclay ${ }^{1}$, Chen Zeng ${ }^{4}$, Marc S. Weinberg, 5 and Fatah Kashanchi ${ }^{1,7^{*}}$ (D)

\begin{abstract}
Background: HIV-1 patients receiving combination antiretroviral therapy (CART) survive infection but require lifelong adherence at high expense. In chronic cART-treated patients with undetectable viral titers, cell-associated viral RNA is still detectable, pointing to low-level viral transcriptional leakiness. To date, there are no FDA-approved drugs against HIV-1 transcription. We have previously shown that F07\#13, a third generation Tat peptide mimetic with competitive activity against Cdk9/T1-Tat binding sites, inhibits HIV-1 transcription in vitro and in vivo.

Results: Here, we demonstrate that increasing concentrations of F07\#13 $(0.01,0.1,1 \mu \mathrm{M})$ cause a decrease in Tat levels in a dose-dependent manner by inhibiting the C $\mathrm{dk} 9 / \mathrm{T} 1$-Tat complex formation and subsequent ubiquitinmediated Tat sequestration and degradation. Our data indicate that complexes I and IV contain distinct patterns of ubiquitinated Tat and that transcriptional inhibition induced by F07\#13 causes an overall reduction in Tat levels. This reduction may be triggered by F07\#13 but ultimately is mediated by TAR-gag viral RNAs that bind suppressive transcription factors (similar to 7SK, NRON, HOTAIR, and Xist IncRNAs) to enhance transcriptional gene silencing and latency. These RNAs complex with PRC2, Sin3A, and Cul4B, resulting in epigenetic modifications. Finally, we observed an F07\#13-mediated decrease of viral burden by targeting the R region of the long terminal repeat (HIV-1 promoter region, LTR), promoting both paused polymerases and increased efficiency of CRISPR/Cas9 editing in infected cells. This implies that gene editing may be best performed under a repressed transcriptional state.

Conclusions: Collectively, our results indicate that F07\#13, which can terminate RNA Polymerase II at distinct sites, can generate scaffold RNAs, which may assemble into specific sets of "RNA Machines" that contribute to gene regulation. It remains to be seen whether these effects can also be seen in various clades that have varying promoter strength, mutant LTRs, and in patient samples.
\end{abstract}

Keywords: HIV-1, Transcription, Latency, Gene silencing, CART, CRISPR

\footnotetext{
*Correspondence: fkashanc@gmu.edu

${ }^{7}$ Laboratory of Molecular Virology, George Mason University, Discovery

Hall Room 182, 10900 University Blvd., Manassas, VA 20110, USA

Full list of author information is available at the end of the article
} 


\section{Background}

Retroviruses appear to be simple yet perform complex functions. They integrate into host chromosomal DNA and utilize the host's replication machinery. The retrovirus human immunodeficiency virus-1 (HIV-1) has been heavily studied in recent years, yet no permanent cure has been discovered. Epidemiological data estimates about 36.7 million people worldwide are infected with HIV-1 and about 2 million new infections occur yearly [27]. There are multiple complications associated with chronic infection, such as HIV-1 associated neurocognitive disorders (HAND), which encompasses neurocognitive impairment in about $50 \%$ of patients despite the use of combination antiretroviral therapy (cART) [23, 26, 30, 34]. This chronic state, especially under cART, promotes a viral state of latency that may be represented by low level manifestations of viral products $[7,18]$. Therefore, it is critical to not only understand the basic mechanisms of pathogenesis but also discover new treatments to combat the virus.

Resting T-cells or myeloid cells that are quiescent have been shown to allow a state of latency $[41,56,71]$ with short bursts of small transcripts during a low or basal transcriptional state [1]. However, to date, there are no FDA-approved drugs against latency in treatment of HIV-1/AIDS patients. For full-length HIV-1 transcription, a combination of stimuli, such as T-cell activation and translation of the viral protein Tat, must occur. Tat is synthetized from a doubly spliced message which is initially able to be transcribed after T-cell receptor (TCR) activation via co-stimulation of CD3 and CD28 [38]. Following an initial round of transcription, Tat and NF- $\mathrm{KB}$ driven transcription generate mRNA production through both initiation and elongation; this is accomplished by Tat binding to TAR and recruitment of positive transcription elongation factor $\mathrm{b}$ (P-TEFb) [14, 41, 48]. This interaction results in the activation of $\mathrm{P}-\mathrm{TEFb}$ kinase complex and phosphorylation of RNA Polymerase II (Pol II). The hyperphosphorylated Pol II is then able to read through nucleosomes containing chromatin complexes and stop at the $3^{\prime}$ LTR. The activation signals through the TCR, as well as ERK1/2, aid in de novo Tat synthesis and elicit transcriptional elongation [38].

Approximately half of those individuals infected with HIV-1 receive cART, which is typically comprised of a cocktail of inhibitors which target viral processes including entry, reverse transcription, integration, and protease-mediated cleavage [20, 32, 35, 44, 77]. Nevertheless, these therapies are ineffective at eradicating HIV-1. This is due to several reasons including lack of strict patient adherence to complex drug regimens, the development of viral resistance over time, inefficient and inconsistent penetration into tissues including the central nervous system (CNS) which thereby contributes to the formation of latent viral reservoirs, and the lack of specific transcriptional inhibitors in the treatment regimen $[60,65$, 77].

To date there are at least six mechanism of HIV-1 transcriptional latency, which include: binding and sequestration of NF- $\mathrm{KB}$ in the cytoplasm, epigenetic silencing of Nuc-1 region at the transcriptional start site, transcriptional interference with Pol II from upstream or antisense promoters, sequestration of $\mathrm{P}-\mathrm{TEFb}$ in the nucleus through 7SK RNA, BRD4/Tat competition for the HIV-1 promoter, and transcriptional silencing through non-coding viral RNA $[1,5,24,48,63,72]$. Specifically, P-TEFb binding to Tat can initiate transcription [6] as well as recruit the super elongation complex (SEC), which contains ELLI, AFFI, ENL, AF9, and PAFc [14, 42, 76]. The $\mathrm{P}-\mathrm{TEFb} / \mathrm{Tat}$ complex enhances transcription by improving the processivity of Pol II [71] but can be disrupted by BRD4 through competitive inhibition of the Tat-binding site [8].

The HIV-1 LTR recruits proteins that contribute to nucleosome assembly and epigenetic silencing, although most Pol II molecules that are paused produce short transcripts that could serve as substrates for Dicer processing and micro-RNA (miRNA) generation $[4,39,45$, 59]. Similarly, long non-coding RNAs (lncRNAs) can also initiate latency by various mechanisms including epigenetic modifications, chromatin remodeling, and transcriptional silencing, among others [51, 62]. For instance, T-cells express a lncRNA known as NRON, which binds and degrades Tat, contributing to HIV-1 latency [43]. Also, 7SK small nuclear RNA (snRNA) sequesters $\mathrm{P}-\mathrm{TEFb}$, thereby preventing transcription [40].

Our laboratory has previously shown that small Tat peptides as well as ATP analogs can either compete for Tat binding or bind to $\mathrm{Cdk} 9$, resulting in inhibition of transcription. The Tat peptide mimetic F07\#13 and ATP analog CR8\#13, as well as Flavopiridol, inhibit transcription both in vitro and in vivo $[15,66,68,69]$. F07\#13 and CR8\#13 were effective in cell lines as well as primary cells with low toxicity and transcriptional inhibition of multiple HIV-1 clades [12, 69].

In this manuscript, we have extended our previous findings on F07\#13 and show that this peptide mimetic is able to inhibit elongation by Pol II and allow an increase of a novel form of HIV-1 non-coding RNA (TAR-gag). A study describing this RNA has previously been published by our laboratory $[1,7]$. Similar to cellular RNAs, such as NRON, 7SK, HOTAIR, and Xist, transcriptional gene silencing (TGS) and latency of HIV-1 is promoted by the binding of viral lncRNAs to novel cellular targets [1]. The new RNA/protein complexes may allow multiple functions including methylation of histone tails (i.e. through 
PRC2), chromatin compaction (i.e. through Sin3A), and degradation of Tat (i.e. through Cul4B). This mode of action from the viral (or cellular) non-coding RNAs (ncRNA) resemble other RNA-assembled structure, such as ribosomes, where RNA serves as a scaffolding molecule to create a specific set of "RNA machines" that can potentially regulate transcription and DNA biology. Implications of these findings will be further discussed in the "Results" and "Discussion" sections.

\section{Results}

\section{Effect of F07\#13 on Tat levels}

HIV-1 Tat exists in multiple distinct complexes (large, medium, and small) in cells where the small complex contains Tat and Cdk9/T1 protein complex [69]. The small complex is believed to be important for HIV-1 Tat activated transcription and is detected in a number of cell lines and primary infected cells [9, 10, 40, 47]. Here, we first examined whether F07\#13 had any effect on Tat levels in cells. Therefore, we transfected Jurkat cells with a dual-tropic wild-type viral construct (89.6) along with a Tat plasmid (CMV-Flag-Tat ${ }_{101}$ ). We have previously used this Tat construct in transfections and were able to detect Tat levels in cells using Flag antibody [3, 22]. Results of such an experiment are shown in Fig. 1a where Tat was specifically immunoprecipitated only when anti-Flag antibody was used. A construct of Tat, Tat (86), which did not contain Flag-Tag, was not precipitated under these conditions (compare lanes 3 and 4). We next explored the effect of F07\#13 on Tat levels and found that Tat was present in detectable amounts; however, when F07\#13 (0.01, $0.1,1 \mu \mathrm{M}$ ) was added to cells $24 \mathrm{~h}$ post-transfection with Flag-Tat $_{101}$ or 89.6 and incubated for $48 \mathrm{~h}$ with F07\#13, the levels of Tat decreased with increasing concentration of F07\#13 (Fig. 1b). We were surprised by these results as the Tat vector is driven by a CMV promoter and is not regulated by F07\#13 or other inhibitors except NF- $\mathrm{kB}$ inhibitors or Flavopiridol [11, 52, 57] (data not shown). Along these lines, when using CMV-Tax as a control (transactivator from HTLV-1), we observed no changes in Tax levels in the presence of F07\#13, indicating that F07\#13 was specific to Tat and not the CMV promoter (Additional file 1: Fig. S1). We therefore reasoned that Tat may be modified (i.e. ubiquitinated) which could target Tat for degradation. Along these lines, Tat has previously been shown to be modified by us and others including acetylation, methylation, and ubiquitination $[19,54,58$, 70].

We next probed for the presence of ubiquitinated-Tat (Ub-Tat) using Flag immunoprecipitated (IP) followed by Western blot for presence of ubiquitin conjugates. Results in bottom panel of Fig. 1b show that increasing concentration of F07\#13 resulted in detection of Ub-Tat, indicating that Tat may potentially be modified. Quantification of total ubiquitinated proteins are graphed underneath the blot. Also, a recent report has shown that Tat is stabilized by the de-ubiquitinase USP7, leading to enhanced viral production [2]. Therefore, we performed another similar experiment with the addition of a proteasome inhibitor (MG132) and a de-ubiquitin inhibitor (P5091). Cells were transfected with both 89.6 and the Flag-Tat $_{101}$ vector and then treated with F07\#13 $(1 \mu \mathrm{M})$ for $48 \mathrm{~h}$. Twenty-four hours post F07\#13 treatment, cells were treated with MG132 $(10 \mathrm{ng} / \mathrm{mL})$ or P5091 $(3 \mu \mathrm{M})$ and incubated for $24 \mathrm{~h}$. Results in Fig. 1c show that Tat levels were decreased with F07\#13; however, addition of P5091 greatly reduced Tat levels. As a follow-up, we performed a Western blot with $\alpha$-ubiquitin antibody and observed an increased level of Ub-Tat when using P5091. Quantifications of total ubiquitinated proteins are graphed below the blot. Collectively, these data indicate that F07\#13 treated cells, in which interactions between Tat and Cdk9/T1 complexes are inhibited [69], have enhanced Tat-ubiquitination and potential degradation.

\section{Effects of F07\#13 on various Tat complexes}

We next examined the effect of F07\#13 on three distinct Tat complexes using J1.1 cells. Here, we used electroporation to transfect Flag-Tat ${ }_{101}$ into J1.1 cells (containing wild type virus) and obtained whole cell extracts for fractionation using fast protein liquid chromatography (FPLC). We have previously used this method to separate Tat associated complexes (4 distinct complexes) using Flag-Tat antibody from infected cells under high salt conditions $[1,69]$. The fractions were further concentrated using nanoparticles (NT084) and run on a 4-20\% Tris-glycine gel for Western blot analysis. Results in Fig. 2a show that Tat separated into three distinct fractions ranging from small molecular weight $(<300 \mathrm{kDa}$; lanes $8-10)$ to medium size (300-600 kDa; lane 5) and large molecular weight (1.2-2.2 MDa; lane 2) complexes. These complexes were previously designated as Complexes I-IV from these infected cells [69]. However, complex II did not contain any Tat protein. Importantly, F07\#13 treated cells exhibited a disappearance of most of the small molecular weight complexes (Complex IV). Control IP without antibody was used for these fractions (Protein A/G only), followed by Western blot with anti-Flag antibody. Total quantification of each fraction in the presence and absence of F07\#13 is shown in Fig. 2b. We then treated the IP blots with $\alpha$-ubiquitin antibody and observed a distinct pattern of ubiquitination in one of the lanes for Complex IV (Fig. 2c; lane 


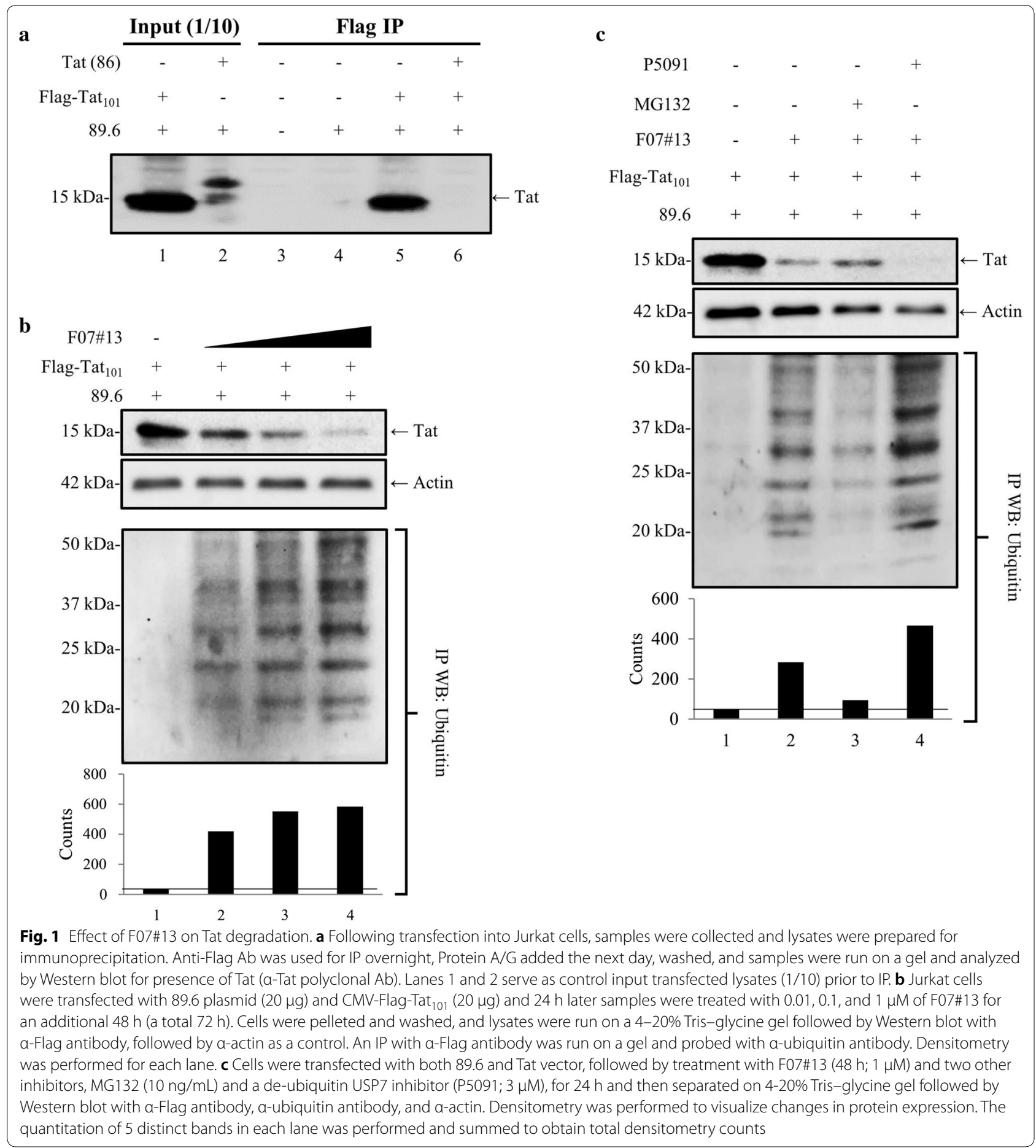

9), but a more prominent pattern of ubiquitination for Complex I (Fig. 2c; lane 2). This pattern of ubiquitination has previously been observed for Tat and a number of other viral transactivators $[2,13,16,33,61,64$, $67,73]$. Collectively, these data indicate that Tat ubiquitination may be regulated by F07\#13, resulting in lower levels of Tat in treated cells.

\section{Presence of novel HIV-1 ncRNA (TAR-gag) in large complexes co-sedimenting with Tat}

We have recently shown that the HIV-1 promoter makes 4 distinct RNA molecules, all of which are non-coding $[1,7]$. We used an RNA sequence analysis to define the $3^{\prime}$ ends of these 4 transcripts [1,7], which are consistent with the presence of paused Pol II on the HIV-1 


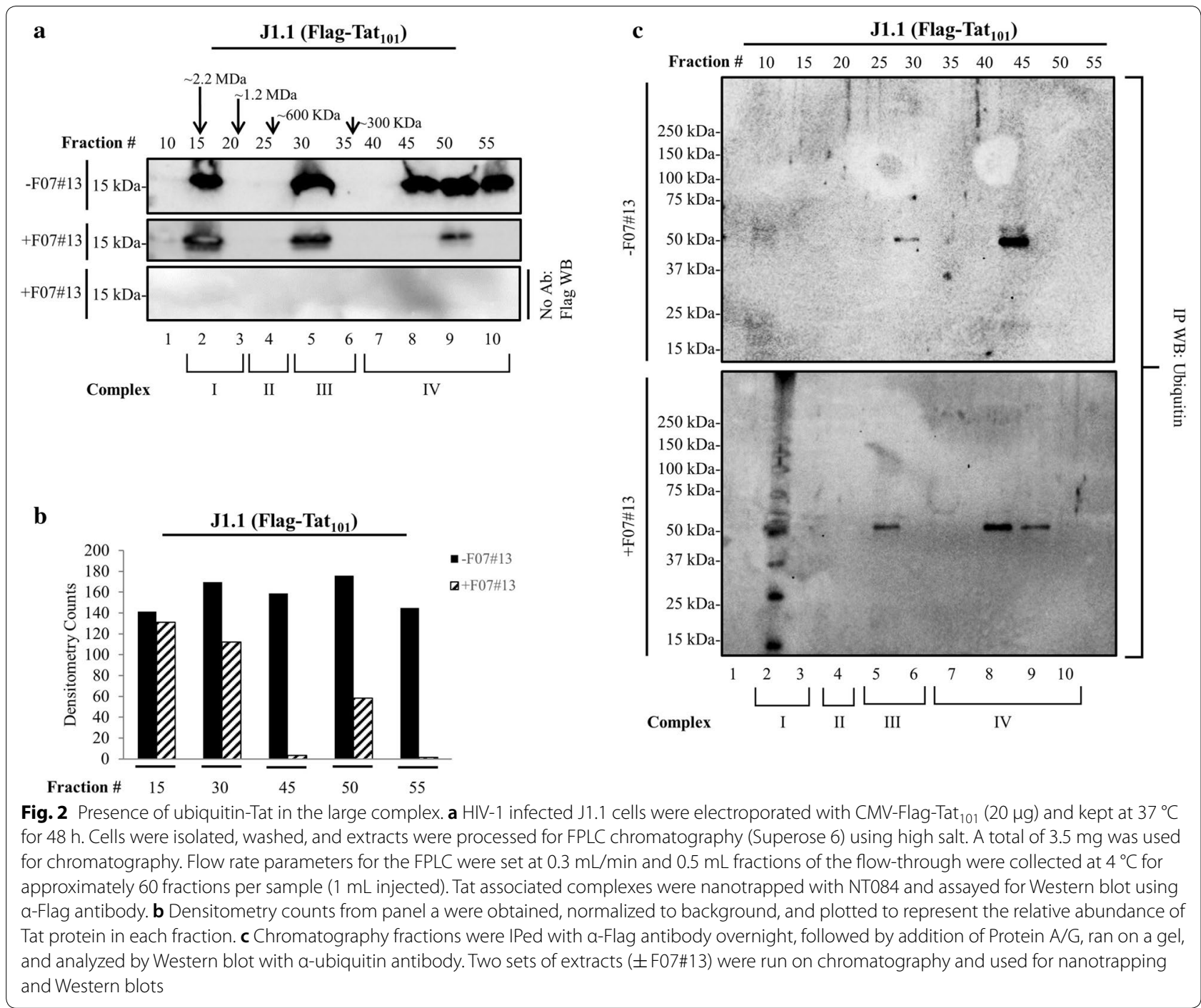

genome as shown by the Karn lab [36]. Our previous data has shown that these RNAs can exist intracellularly and extracellularly; however, the nature of the associated protein complexes are not known for the extracellular environment (exosomes from infected cells contain these RNA molecules) [1, 7]. As these RNA sequences all contain TAR RNA, they all have the potential to bind and sequester Tat protein. Here, we IPed from Flag-Tat ${ }_{101}$ transfected cells using previously established antibodies against proteins that complex with RNA and are responsible for TGS [1]. Following pre-clearing with IgG, we then used antibodies against PSMD11 (ubiquitin protein complex), Sin3A (responsible for binding to HDAC-1 and part of the suppressive SWI/SNF complex), PRCs (known RNA binding complexes containing EZH2), and Cul4B (ubiquitin complex marker) for our IPs. We then washed the complexes with TNE300 followed by TNE50 and isolated RNA for subsequent RT-qPCR RNA analysis. It is important to note that there were no crosslinking reagents used in these IPs. Results in Fig. 3a show that in F07\#13 treated cells, TAR-gag was bound to PRC2, Sin3A, Cul4B, and low levels of DNMT3A in the large complex (Complex I). However, TAR-gag was mostly bound to Sin3A and Cul4B in the medium size complexes (Complex III). We also observed low levels of Sin3A binding to TAR-gag from Complex IV fractions. Interestingly, we have previously observed increased association between TAR-gag, HDAC-1, Sin3A, and PIWIL4 in F07\#13 treated HIV-1 positive cells [1]. Nevertheless, these previous observations used whole cell extracts and not chromatographic separations as observed in Fig. 3a. Control 7SK RNA expression was also tested in these fractions, as we have previously shown that 7SK elutes mostly with complex II [53]. Results in Fig. 3b show the presence of 7SK in complex II, which is distinctly different from where TAR-gag elutes. Collectively, these results 


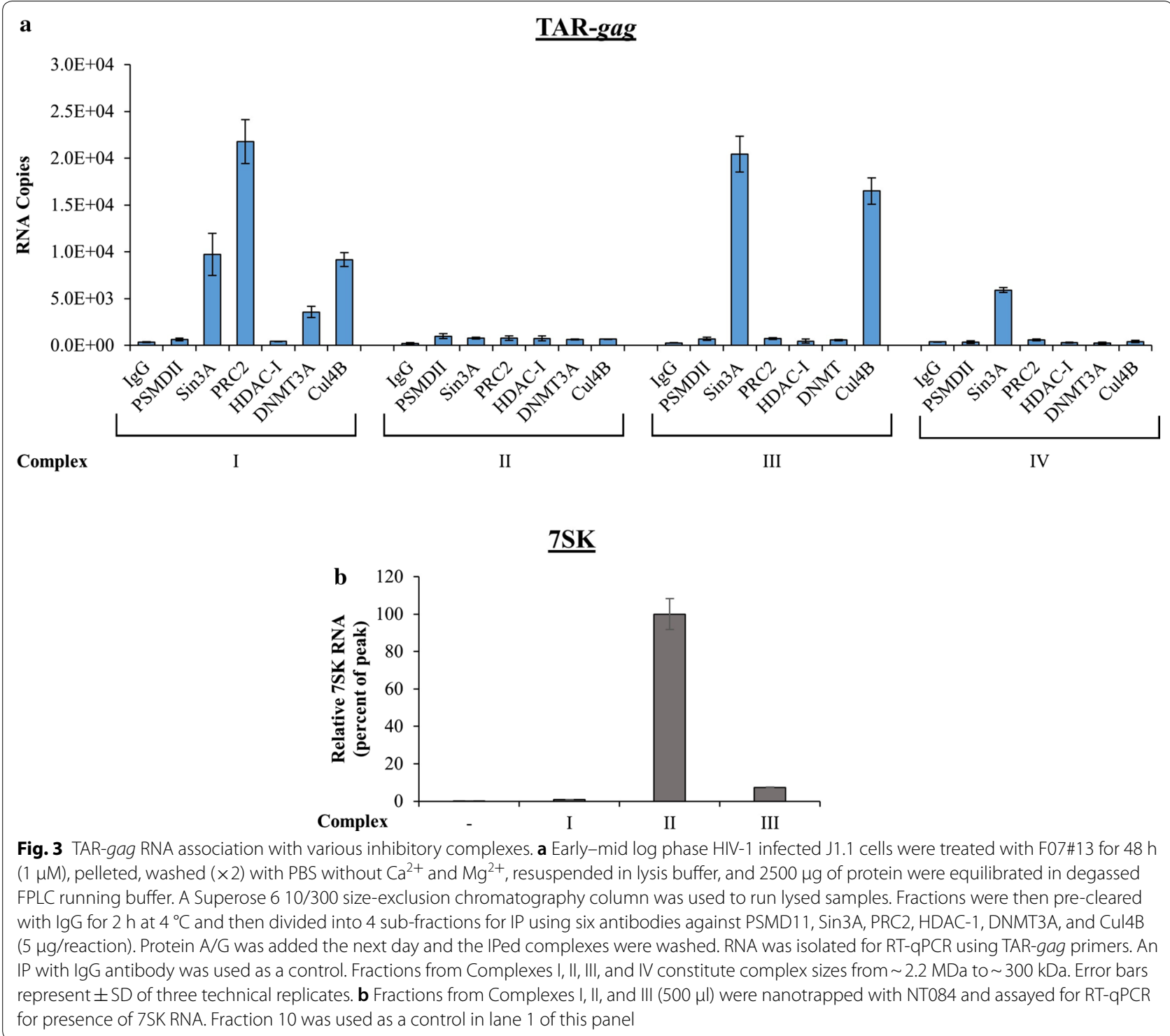

indicate that HIV-1 lncRNAs have the potential to bind to proteins that can regulate $\mathrm{HIV}-1$ gene expression through an RNA-protein complex and potentially act as "RNA machines".

\section{Presence of viral RNA protein complexes in PBMCs}

Here, we asked whether RNA from primary T-cells infected with dual tropic virus could still bind to some of the factors complexed with TAR-gag. We used a previously published procedure where fresh primary PBMCs $\left(1 \times 10^{7}\right.$ cells $)$ were cultured with PHA/IL-2 for 7 days and then infected with HIV-1 89.6 strain (MOI:1) [7]. Three days later they were treated with F07\#13 (once every other day at $0.1 \mu \mathrm{M}$ ) for a total of 20 days. Cells were collected and lysates were loaded onto a sizing column under high salt. We then isolated specific fractions and IPed ( $250 \mu \mathrm{L}$ aliquots) with either IgG, PRC2, Sin3A, or Cul4B (5 $\mu \mathrm{g}$ of each). Not enough material was obtained for IP against HDAC-1 or DNMT3A proteins. Following overnight IPs, complexes were collected using Protein A/G beads. RNA was isolated and RT-qPCR was performed for the presence of TAR-gag. Results in Fig. 4a show that there were specific complexes made in the large Complex I fraction where we observed PRC2, Sin3A, and Cul4B binding to TAR-gag. Complex II, similar to J1.1 fractions, did not contain appreciable amounts of RNA associated complexes; however, we observed the presence of Sin3A but no Cul4B in Complex III. Unlike the J1.1 extracts, we observed PRC2 binding in Complex IV in addition to Complex I. It is important to 
a $\underline{\text { TAR-gag }}$

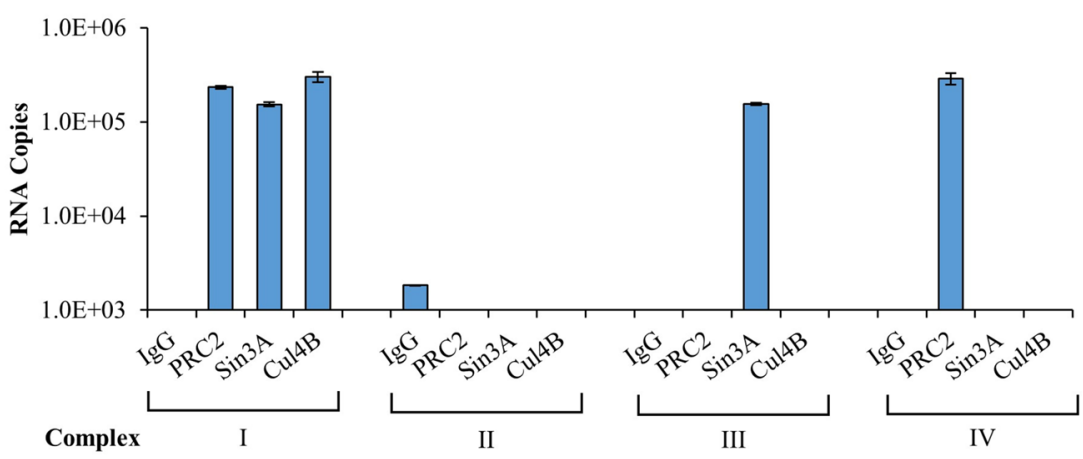

$\underline{\text { 7SK }}$

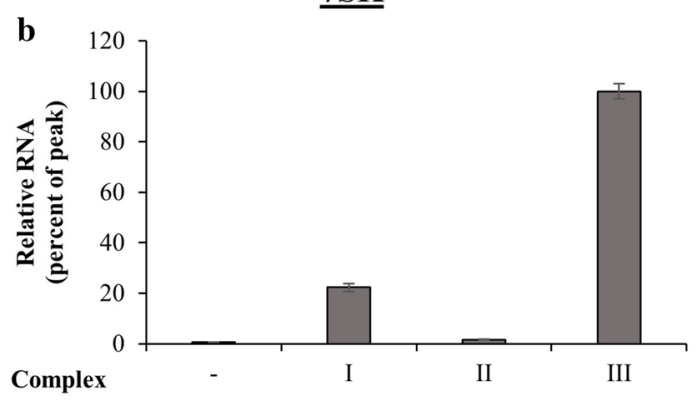

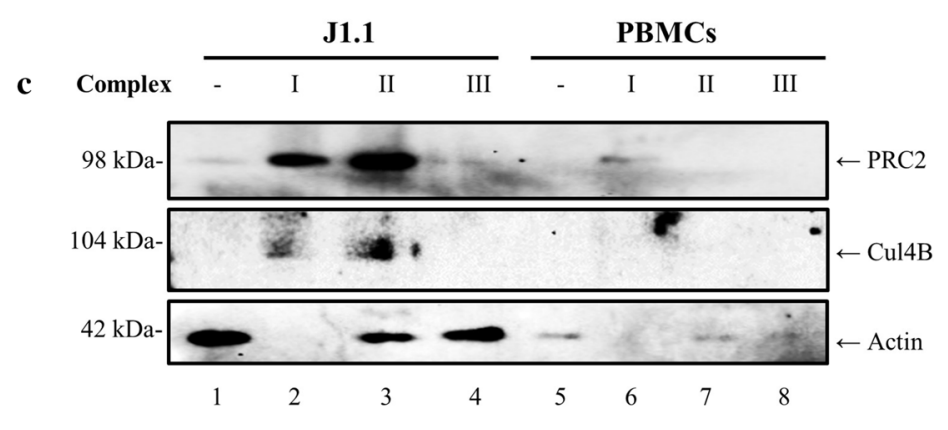

Fig. 4 Presence of HIV-1 RNA associated complexes in multiple HIV-1 infected whole cell extracts. a Fresh primary PBMCs (10 ${ }^{7}$ cells) were cultured with PHA/IL-2 for 7 days and infected with HIV-1 89.6 strain (MOI:1) [7]. Three days later they were treated with F07\#13 (once every other day at $0.1 \mu \mathrm{M})$ for a total of 20 days. Cells were collected and lysates were loaded onto a sizing column under high salt. Column fractions were then IPed with antibodies against PRC2, Sin3A, Cul4B, and IgG. Following IP, RNA was isolated and samples were processed for RT-qPCR using primers against TAR-gag. Non-specific lgG background IPs were used as a control. Fractions from Complexes I, II, and III (500 $\mu$ I) of infected PBMCs were nanotrapped with NT084 and assayed for RT-qPCR for presence of 7SK RNA (b) or half of the samples were run on an SDS/PAGE and Western blotted for presence of PRC2, Cul4B, actin, and Sin3A (data not shown) (c). Fraction 10 was used as a control in lane 1 of panels $b$ and c. Error bars represent \pm SD of three technical replicates

note that we do not know if these protein complexes are all on one RNA structure or if there are multiple forms of heterogeneous populations of RNA-protein complexes (i.e. Complex I). That would require further purification using mono-S and mono-Q columns or other more robust matrices, such as hydroxyapatite. Interestingly, the three proteins (PRC2, Sin3A, and Cul4B) complexed to TAR-gag RNA were all present in the higher molecular weight Complex I. We next performed RT-qPCR for the presence of 7SK RNA expression, and unlike J1.1, we observed some of the 7SK RNA present in Complex I, but mostly in Complex III (Fig. 4b). We currently do not understand the reasoning for this shift of the 7SK RNA into smaller complexes in primary cells infected with 89.6; however, we have observed presence of potentially two different RNAs in Complex I/III versus II, since the melting curve for the RNA in Complex II was slightly different than the other two complexes $\left(83{ }^{\circ} \mathrm{C}\right.$ vs. $85{ }^{\circ} \mathrm{C}$; data not shown). Finally, we performed a similar pulldown experiment using NT084 from these fractions and
Western blotted for presence of PRC2, Sin3A, and Cul4B. Data in Fig. 4c show that PRC2 (EZH2 subunit) was present in Complexes I and II in J1.1, as well as low levels of $\mathrm{Cul} 4 \mathrm{~B}$ in the same fractions. Results from PBMC Western blots were mostly unclear due to low protein recovery; however, we were able to observe a faint band for PRC2 in Complex I. Actin was used as a control for both cell types. Collectively, these data imply that TAR-gag maybe complexed with cellular proteins that normally regulate gene expression.

\section{Effect of F07\#13 on HIV-1 LTR genome editing}

We have recently shown that, contrary to widelyaccepted latency models, the HIV-1 LTR is not a silent promoter, and Pol II is capable of transcribing through the LTR R/U5 region as well as the early stages of the gag gene between nucleosomes 2 and 3 in the presence of external signals such as exosomes [7]. This data was especially significant as it points toward an RNA polymerase that may alter the HIV-1 LTR DNA (by negative 
supercoiling, nucleosome remodeling, presence of various paused complexes, etc.), which may affect target recognition by guide RNA (gRNA) and ultimately gene editing. Therefore, our reasoning for performing these next set of experiments was that if the HIV-1 DNA is constantly occupied for transcriptional read-through resulting in production of ncRNA, then it may be difficult for the gRNA to find its target DNA, especially in the LTR, and allow subsequent DNA editing. Here, we asked whether F07\#13 could potentially aid in pausing of Pol II to allow for a better gRNA recognition and gene editing.

To perform these experiments, we first had to synthesize a series of gRNAs that would target the $\mathrm{R}$ region of the LTR. The vector system used caused double-stranded breaks guided by a 20-nt gRNA sequence within an associated CRISPR-RNA transcript [25]. To determine whether viral LTR could be targeted in infected latent cell lines, we treated three infected cell types with Cas9 and TAR gRNAs (gRNAs 1-8). Out of these 8 RNAs, we observed two gRNAs, gRNA 3 and 6, that showed partial editing (data not shown). Therefore, we focused on these two gRNAs for our subsequent set of experiments. The sequences and the directions of the gRNAs are shown in Fig. 5a.

We first asked whether TAR gRNA 3/6 (TAR3/6) vectors could show presence of DNA damage response proteins, such as DNA-PK, on the HIV-1 promoter. Here, we transfected J1.1, CHME-5/HIV [74], and U1 cells with Cas9 and TAR3/6 (1:10 ratio). All cells were treated with cART $(10 \mu \mathrm{M})$ for 1 week prior to transfections to eliminate any residual virus. Cells were kept in culture for 5 days and subsequently cross-linked for chromatin immunoprecipitations (ChIPs) using various antibodies including $\alpha$-Pol II, $\alpha$-Cdk9 (T186), $\alpha$-p-H2AX, $\alpha$-DNA-PK, and $\alpha$-ARIDA (Baf 250). Results in Fig. 5b show that mock treated cells contained Pol II and low levels of Cdk9 (T186) on the promoter. However, cells treated with triple plasmid (Cas9+TAR3/6) showed presence of p-H2AX, but more importantly DNA-PK and ARIDA, on the LTR. The presence of DNA-PK on the LTR is an indication of potential recruitment of DNA repair machinery, and the presence of ARIDA (a subunit of suppressive SWI/SNF complex) is an indication of suppressive chromatin involved in transcriptional silencing and potentially DNA repair.

We next asked whether inhibition of either DNAPK or Ataxia telangiectasia mutated (ATM) kinase in Cas9 treated cells could result in apoptosis. Our rationale for these experiments was that if the HIV-1 genome is not properly repaired, then the cells might be pushed toward apoptosis. For this, we used inhibitors of ATM and DNA-PK that are being developed as potential therapeutics for the treatment of cancer [21]. Low concentrations of inhibitors for DNA-PK (Nu 7441) or ATM (KU 55933) were used in both infected and uninfected cells [29]. Results in Fig. 5c show that when infected cells are treated with either inhibitor, there is an increased level of apoptosis in infected T-cells but not in uninfected cells. Collectively, these results imply that the targeted Cas9 vectors may use either DNA-PK or ATM for repair and their inhibition pushes cells toward apoptosis.

We next performed a similar experiment as in Fig. 5b, but we added Trichostatin A (TSA) after 5 days to activate the latent viruses. The rationale for these experiments was that if the HIV-1 LTR genome was indeed mutated with Cas9+TAR3/6 constructs, then the resulting viral particles from these cells would be either noninfectious or contain particles with reduced infectivity. To assay for the released viruses, we utilized nanoparticles to trap and concentrate HIV-1 particles (NT086) and added the virus/nanoparticles onto the reporter TZM-bl-Luc cells [37]. Results in Fig. 5d indicate that viruses generated from latent cell lines released following Cas9+TAR3/6 treatment contained low levels

\footnotetext{
(See figure on next page.)

Fig. 5 DNA-PK on the HIV-1 genome following Cas9+TAR3/6 transfection and alterations in cutting following F07\#13 treatment. a Schematic of the HIV-1 proviral genome, which highlights the $5^{\prime}$ LTR of HIV-1. A series of gRNAs was designed to target the essential TAR loop required for Tat binding and proviral reactivation. b Three infected cell types (J1.1, CHME5/HIV, and U1) were grown in the presence of cART for 1 week prior to transfection. Cells were electroporated with three constructs at a 1:10 ratio $\left(0.1 \mu \mathrm{g} / 1 \mu \mathrm{g}\right.$ of Cas9+TAR3/6) and kept in culture for 5 days. Approximately $1 \times 10^{7}$ cells were used for ChIP assay using antibodies $(10 \mu \mathrm{g})$ against Pol II large subunit, Cdk9 (T186), p-H2AX, DNA-PK, and ARIDA. Following DNA purification, samples were PCR amplified using LTR primers and run on a 2\% Agarose gel. c Similar to panel b except cells were treated with two inhibitors after 5 days. Both inhibitors, DNA-PK inhibitor (Nu 7441, $0.2 \mu \mathrm{M}$ ) and ATM inhibitor (KU 55933, $1 \mu \mathrm{M}$ ), were used for a 2 day treatment of either uninfected (Jurkat) or infected (J1.1) cells prior to CellTiter-Glo. Positive control Fas antibody was used for apoptosis on both cell types. d Similar experimental design to panel b, except J1.1, CHEM5/HIV, and U1 cells were treated with $100 \mathrm{nM}$ TSA after 5 days of transfection. Viruses were isolated from the supernatants with NT086 particles and added to TZM-bl-Luc cells. e A similar experiment as outlined in panel d; however, U1 and ACH2 cells were treated 1 day prior to PHA/PMA treatment with either F07\#13 (Day 4), Cas9+TAR3/6, or both together and analyzed by RT-qPCR for the presence of TAR RNA. ${ }^{*} p$ value $\leq 0.05 ;{ }^{* * *} p$ value $\leq 0.001$. $\mathbf{f}$ Latent PBMCs (3 independent donors) were created as described previously [7]. After CART/IL-7 addition, samples were divided into 4 sections; two were electroporated (210 V) with TAR3/6 DNA \pm F07\#13 and kept in culture for 4 days. They were then treated with PMA/PHA for 2 days prior to p24 Western blot
} 
a

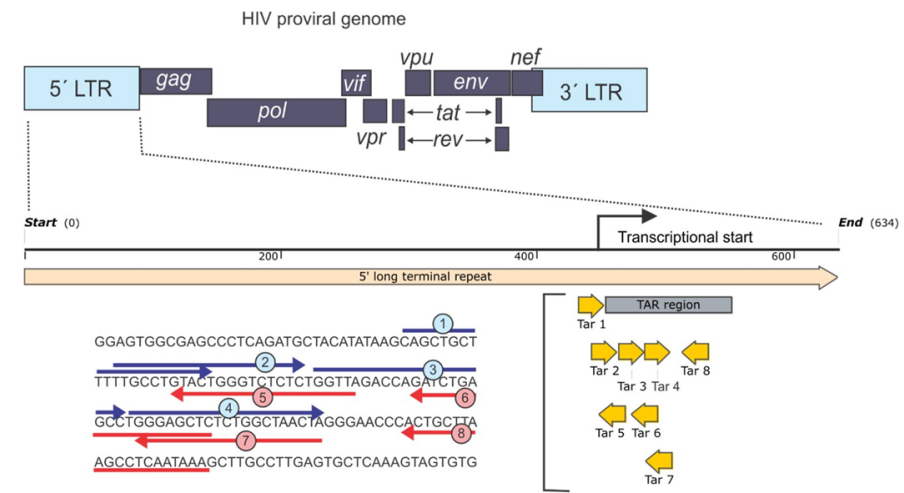

b

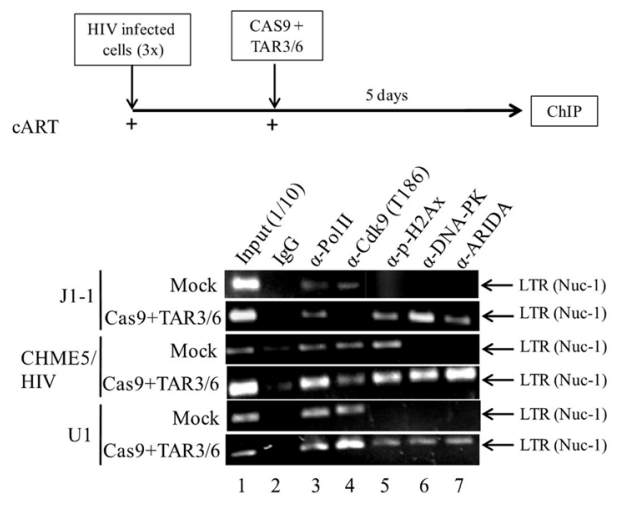

d
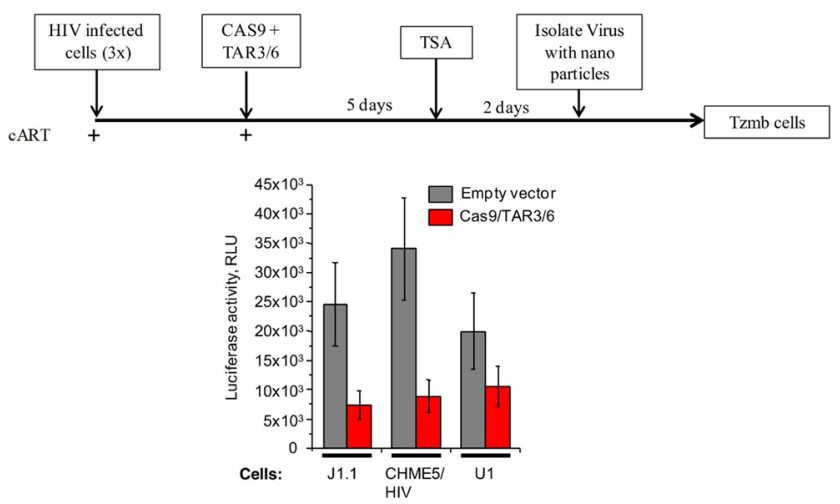

f

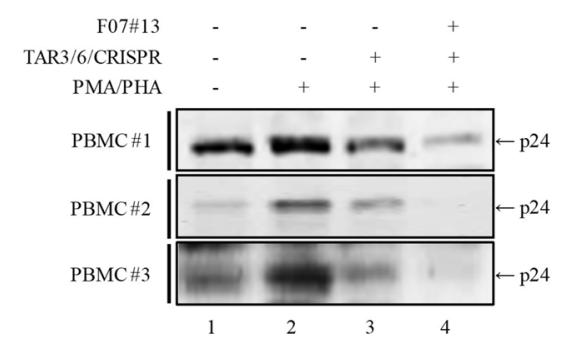

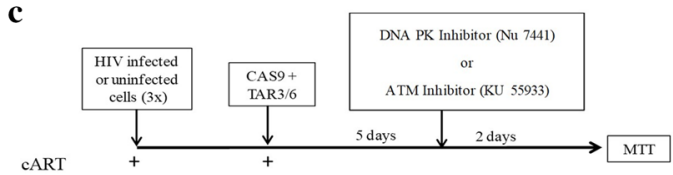

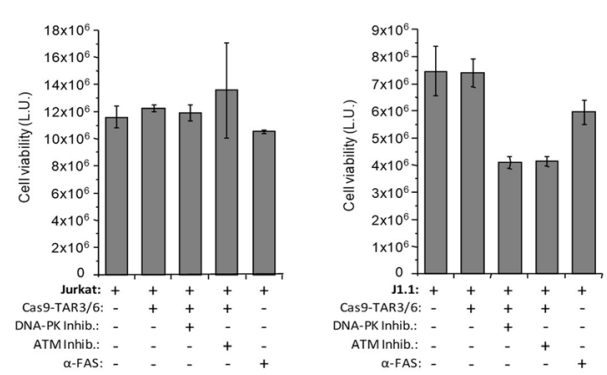

e

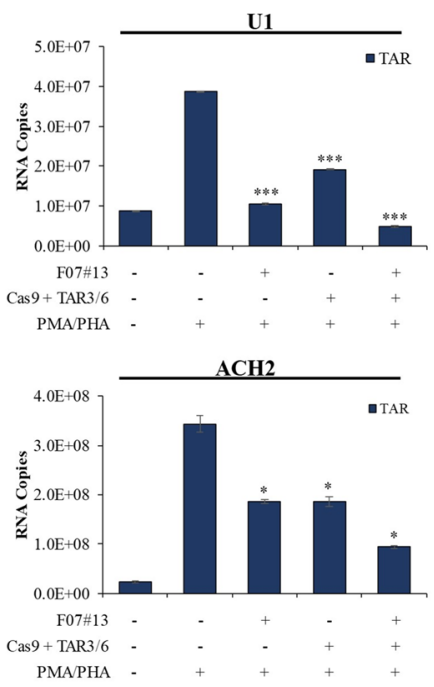


(2-5 fold) of virus. Positive control experiments using no Cas9+TAR3/6 contained high levels of virus following induction with TSA from all tested cell types. Finally, we performed a similar experiment as outlined in Fig. 5d but treated cells 1 day prior to PHA/PMA treatment with F07\#13 (Day 4). Here, the rationale was that if Pol II is paused following F07\#13 treatment, then there would be a higher chance of gRNA finding its target DNA for editing, resulting in less viral product formation (i.e. Gag p24). Results of such an experiment are shown in Fig. 5e, where PHA/PMA treatment showed an increase in TAR RNA levels in myeloid and T-cells (U1: $3.9 \times 10^{7}$ copies; $\mathrm{ACH} 2: 3.4 \times 10^{8}$ copies); a drop of RNA when using F07\#13 (U1: $1.0 \times 10^{7}$ copies; ACH2: $1.9 \times 10^{8}$ copies); a drop of RNA when using Cas9+TAR3/6 (U1: $1.9 \times 10^{7}$ copies; ACH2: $1.9 \times 10^{8}$ copies); and a larger drop in RNA when using both F07\#13 and Cas9+TAR3/6 (U1: $4.8 \times 10^{6}$ copies; $\mathrm{ACH} 2: 9.4 \times 10^{7}$ copies). Finally, to test whether editing could take place in primary cells, we used a previously published latent model [7]. Three independent PBMCs were seeded at $10^{7}$ cells $/ \mathrm{mL}$ and treated with PHA/IL-2 for 7 days. They were then infected with HIV-1 89.6 (MOI 10) for 3 days and treated with cART and IL-7 for another 9 days. The samples were divided into 4 , out of which 2 were electroporated $(210 \mathrm{~V})$ with TAR3/6 vectors $(20 \mu \mathrm{g}) \pm$ F07\#13 $(1 \mu \mathrm{M})$ and kept in culture for 4 days. They were then treated with PMA/PHA for 2 days prior to cell harvest and lysis. Cell lysates were then ran on a $4-20 \%$ gel for Western blot using antip24 antibody. Data in Fig. $5 \mathrm{f}$ show that all three PBMCs contained background levels of gene expression under these conditions (lane 1); however, upon addition of PMA/PHA, a robust gene expression was observed (lane 2). Samples that received TAR3/6 vectors were not as induced as the control (compare lane 3 to 2), and F07\#13 treated cells showed minimal induction of gene expression and p24 levels (lane 4). Collectively, these data indicate that F07\#13 may potentially slow down transcription, which would allow for better gene editing in these cells.

\section{Discussion}

Today, HIV-1/AIDS patients primarily receive cART. This therapy works by targeting several steps of the viral life cycle including viral entry, reverse transcription, integration, and viral maturation. However, cART does not cure HIV-1 as it is unable to target latent viral reservoirs [60, 65, 77]. Additionally, there is currently no FDA-approved transcription inhibitor for the treatment of HIV-1. We have recently shown that this lack of a transcription inhibitor allows for the generation of TAR and TAR-gag transcripts [7]. This data is suggestive of paused polymerase sites located at nucleosome 1 and between nucleosome 2 and nucleosome 3, respectively. We have generated the 4 RNA structures based on 4 sequences of lengths +1 to +96 for Sequence I (TAR), +1 to +184 for Sequence II (TAR), +1 to +408 for Sequence III (TARgag), and +1 to +615 for Sequence IV (TAR-gag), and show the potential binding site for PRC2 in Sequences III and IV (Additional file 1: Fig. S2-S6). Importantly, when using F07\#13, TAR-gag is significantly increased, but TAR levels were not [1]. We have previously shown that lower FPLC fractions (\#15-30) presented the most noticeable increase in TAR-gag, suggesting TGS via blockage of elongation and increased protein recruitment by TAR-gag [1].

In the current manuscript, we asked whether F07\#13 had secondary effects on latency. The primary mechanism of F07\#13 was to disrupt Tat interaction with Cdk9/T1 complex and thereby stop or slow down Tat activated transcription [69]. However, we have consistently observed degradation of Tat in F07\#13 treated cells, which was an unexpected finding. We suspected that Tat could be degraded through the ubiquitination and proteasome pathway. Here we have shown a dose-dependent decrease of Tat protein levels in cells treated with F07\#13 (Fig. 1). Furthermore, when fractionating Tat associated complexes from F07\#13 treated cells, we observed specific poly-ubiquitination of Tat from the large complex (Complex I) (Fig. 2), indicating that there was a selective processing of Tat in this complex and not the other Tat associated complexes.

When performing RNA/protein IP, we found TARgag, a novel long HIV-1 ncRNA, associated with multisuppressive protein complexes including Sin3A, PRC2, and Cul4B (Figs. 3, 4). Previous studies have shown the presence of similar RNA/protein complexes from plants [55]. This is also not surprising as mammalian PRC2, which is part of the polycomb complex, is able to bind to RNAs including HOTAIR, Xist, MEG3, ANRIL, PCAT, SChLAP1 (member of SWI/SNF), and ANCR [17, 50, 75]. Therefore, we suspect that one of the primary byproducts of F07\#13 treatment in infected cells is generation of HIV-1 ncRNA that is able to bind Tat (through TAR) and protein complexes (i.e. PRC2, Sin3A, and Cul4B) that may perform a number of functions including epigenetic regulation of either HIV-1 nascent RNA or viral DNA, modification of substrates such as histones (i.e. nucleosomes-1, 2, 3), and/or degradation of substrates such as Tat. Therefore, we collectively consider this new RNA/protein complex as part of an "RNA machine" (Fig. 6) that is mostly generated in the presence of transcription inhibitors. Future experiments using further purification followed by RNA/protein mapping will better determine the specificity of this interaction and 


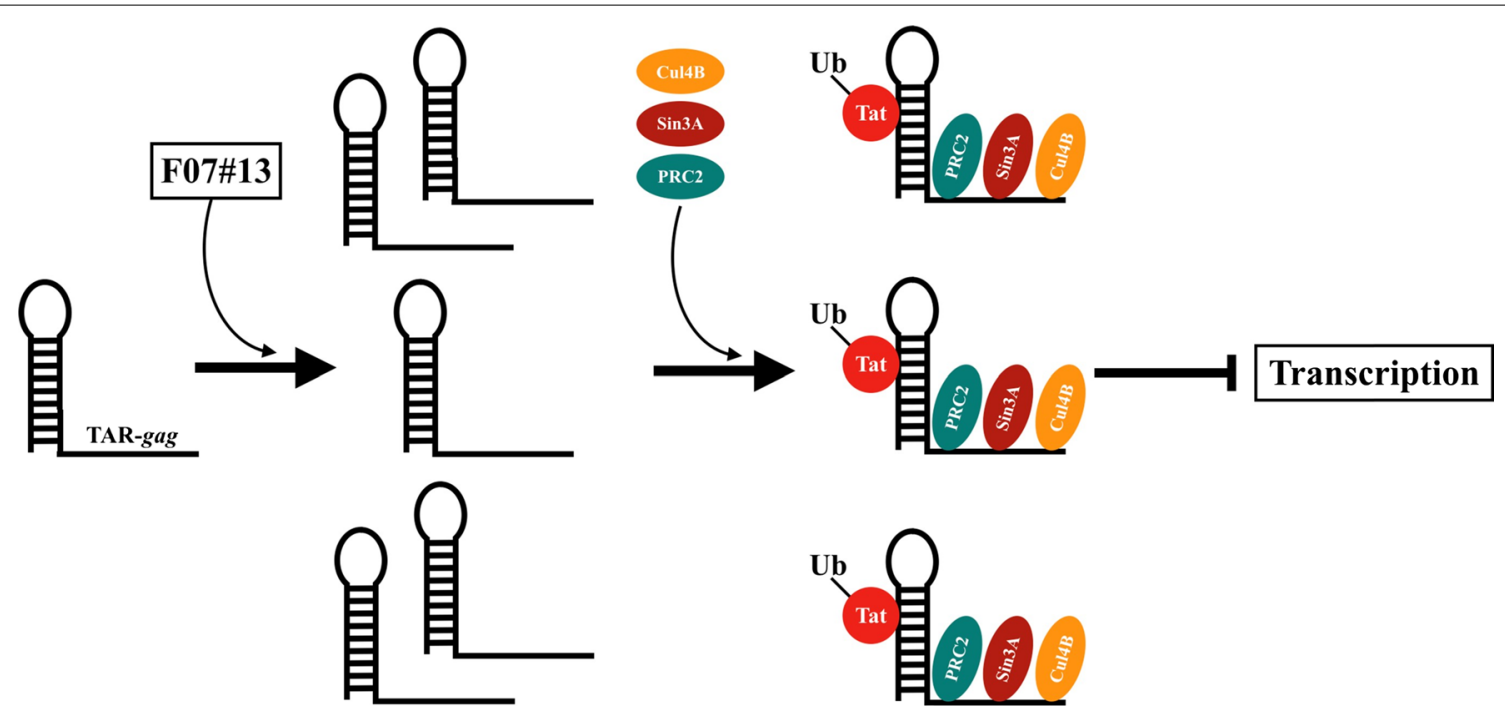

Fig. 6 A proposed model of the effect of F07\#13 on binding to TAR-gag. The model is based on the notion that the ncRNAs (i.e. TAR-gag) are made from HIV-1 LTR and upon the introduction of F07\#13, there is an increase in the copy number of TAR-gag due to non-processive Pol II transcription. The increased abundance of TAR-gag leads to the sequestration of ubiquitinated Tat, potentially through the TAR sequence. The presence of protein complexes with RNA can constitute newly synthesized "RNA machines", which cause the repression of HIV-1 transcription through epigenetic modifications and potentially contribute to gene silencing and latency

its enzymatic activities, especially related to PRC2/RNA binding and Cul4B activity.

Using CRISPR/Cas9 technology against TAR, we found that 2 gRNAs were effective in binding to their target sites and editing the HIV-1 genome in three cell lines infected with LAI strains. These cell lines were of T-cell and myeloid origin. Using chromatin IP (ChIP) assays, we found that levels of $\mathrm{p}-\mathrm{H} 2 \mathrm{AX}, \mathrm{DNA}-\mathrm{PK}$, and ARIDA proteins increased following Cas9+TAR3/6 treatment, which is an indication of repair of the genome. Importantly, the effect of editing increased with F07\#13, indicating that the rate of Pol II loading and transcription may control the activities and efficiency of the gRNA targeting its site on the HIV-1 DNA (Fig. 5). Along these lines, future questions that still need to be addressed include: How does editing differ in active versus inactive sites of integration; does the HIV-1 copy number change (i.e. increase) over time with increasing number of defective viruses versus wild type virus following cART, thereby affecting editing; are there editing differences between infected central, transitional, and effector memory T-cells; and finally, what are the editing differences between T-cells and myeloid (i.e., macrophages, microglia, astrocytes) infected cells. Future in-depth experiments are currently in progress to address the efficacy of F07\#13 inhibition in a humanized mouse model infected with dual-tropic 89.6 HIV-1 under cART and whether F07\#13 treatment can contribute to CRISPR/Cas9 editing in blood and tissues. We have previously published the use of F07\#13 in NOG animals and observed a significant drop of TAR RNA in animals activated with low level irradiation in blood, brain, and lung [1]; however we currently are expanding the number of animals to address the effect of the drug on gene editing in these tissues. These experiments are also being followed with mathematical modeling of short versus long transcripts in various tissues in the animals following treatment. Collectively, our data indicate that F07\#13 not only inhibits Tat binding to Cdk9/T1 complexes but also contributes to transcriptional pausing and increase of viral ncRNAs (i.e. TAR and TAR-gag), which can then sequester Tat and aid in Tat degradation. It remains to be seen whether these effects can also be observed in various clades that have varying promoter strength, mutant LTRs, and in vivo.

\section{Conclusions}

We conclude that the Tat peptide mimetic, F07\#13, induces TGS of HIV-1 by induction of viral ncRNA (i.e. TAR and TAR-gag) and subsequent complexing with transcriptional suppressive proteins (i.e. PCR2, Sin3A, and Cul4B), promoting a TGS "RNA machine", and may elicit Tat degradation by promoting Tat ubiquitination, resulting in inhibition of Pol II elongation. Furthermore, we report F07\#13 synergizes with Cas9+TAR3/6 to impair HIV-1 replication in multiple cell types. These results provide insight into future potential uses of agents (i.e. F07\#13) promoting formation of an "RNA machine" 
with specificity against HIV-1 transcription in clinical settings.

\section{Methods}

Cell culture and reagents

Uninfected T-cell (CEM), chronically HIV-1 infected T-cell lines (J1.1, 8E5, and ACH2), HIV-1 infected promonocytic cell (U1), as well as the promonocytic cell line (OM-10.1), were cultured in RPMI-1640 medium supplemented with $10 \%$ heat-inactivated FBS, $2 \mathrm{mM}$ L-glutamine, $100 \mathrm{U} / \mathrm{mL}$ penicillin, and $100 \mu \mathrm{g} /$ $\mathrm{mL}$ streptomycin. The J1.1 cell line is a Jurkat E6.1 derivative chronically infected with HIV-1 (LAI strain), while the ACH2 cell line was isolated from HIV-1 (LAV strain) infected A3.01 cells. TZMB cells were previously described [39]. HIV-1 89.6 plasmid is a dual-tropic strain. Cells infected with HIV-1 89.6 were treated for 7 days with a protease inhibitor (Indinavir) and nucleoside reverse transcriptase inhibitor (Emtricitabine) at a final concentration of $10 \mu \mathrm{M}$ per drug. Both cell lines and antiretrovirals were obtained from the AIDS Reagent Program (National Institutes of Health).

\section{Antibodies}

Antibodies used for Western blot were $\alpha$-PSMD11 (Sigma; S1574); $\alpha$-Sin3A antibody (Abcam, ab3479); $\alpha$-PCR2 (EZH2) antibody (Cell signaling, 5246P); $\alpha$-HDAC-1 (Abcam, ab7028); $\alpha$-DNA PK (Abcam, ab18192); $\alpha$-ARIDA (Santa Cruz, sc-32761, 1:250); $\alpha$-CUL4B-A412 (Abcam, ab157103, 1:5000); antiDnmt3a (Abcam, ab2850); $\alpha$-Ubiquitin antibody (Abcam, ab7780); Flag M2 antibody (Sigma, F1804), and $\alpha$-Actin (Abcam, ab49900, 1:5000). Other antibodies used for this manuscript included $\alpha$-Pol II (Santa Cruz, sc-899, 1:250), $\alpha$-p-Cdk9 (T-186) (Abcam, ab79178). $\alpha$-p24 and $\alpha$-Nef were obtained from NIH AIDS Reagent Program. Additionally, a cocktail of HIV-1 Tat Monoclonal (4D5.24), HIV-1 Tat Monoclonal (7D5.1), HIV-1 Tat Monoclonal (5A5.3), and HIV-1 Tat (NT3 2D1.1) was obtained from Dr. Jonathan Karn, also through the NIH AIDS Reagent Program. All other antibodies were used at a 1:1000 dilution.

\section{Transfection}

The Cell-Porator $^{\mathrm{TM}}$ [Life Technologies, Inc; Bethesda Research Labs (BRL)] was used to transfect cells per the manufacturer's instructions. Briefly, Jurkat, J1.1, CHME5/HIV, and U1 cell lines were electroporated in RPMI 1640 media containing 10\% FBS and 5\% L-glutamine. The cell lines were transfected with DNA $(20 \mu \mathrm{g})$ at the following parameters: a capacitance of
$800 \mu \mathrm{F}$, low resistance, pulse voltage of $230 \mathrm{~V}$ for cell lines and $210 \mathrm{~V}$ for primary cells, and fast charge rate.

\section{Whole cell extract preparation and analysis by Western blot}

Pellets from infected cells were collected and washed with phosphate-buffered saline (PBS). Subsequently, lysis buffer [50 mM Tris- $\mathrm{HCl}$ ( $\mathrm{pH}$ 7.5), $120 \mathrm{mM} \mathrm{NaCl}, 5 \mathrm{mM}$ EDTA, 0.5\% Nonidet P- 40 , $50 \mathrm{mM} \mathrm{NaF}, 0.2 \mathrm{mM} \mathrm{Na}_{3} \mathrm{VO}_{4}$, $1 \mathrm{mM}$ DTT, and 1 protease inhibitor cocktail tablet $/ 50 \mathrm{~mL}$ (Roche Applied Science)] was used to resuspend pellets, which were then gently vortexed and incubated at $4{ }^{\circ} \mathrm{C}$ (or on ice) for $20 \mathrm{~min}$ with additional vortexing at every $5 \mathrm{~min}$ interval. Centrifugation $\left(10,621 \times g\right.$ for $10 \mathrm{~min}$ at $\left.4{ }^{\circ} \mathrm{C}\right)$ was utilized to separate lysate from supernatant. Bradford protein assay (BioRad) was used to quantitate total protein concertation from collected lysates to be used for analysis by Western blot according to the manufacturer's instructions. A mixture of Laemmli buffer with $20 \mu \mathrm{g}$ of lysate was prepared (by gentle vortexing and heating at $95^{\circ} \mathrm{C}$ for $3 \mathrm{~min}$ ) and loaded onto a 4-20\% Tris-glycine gel (Invitrogen) at a volume of approximately $10 \mu \mathrm{L}$ for each sample. Western blot was run at $100 \mathrm{~V}$ until completed and followed by an overnight transfer at $50 \mathrm{~mA}$ onto PVDF Immobilon membranes (Millipore). A $2 \mathrm{~h}$ incubation at $4{ }^{\circ} \mathrm{C}$ with a mixture of $5 \%$ DIFCO ${ }^{\mathrm{TM}}$ Skim Milk (BD) in PBS with $0.1 \%$ Tween-20 (PBS-T) was used for blocking of non-specific antibody binding on PVDF membranes. Prior to adding primary antibody, a light rinse was performed with PBS-T to remove residual blocking solution. Corresponding primary antibodies were added and incubated with gentle rocking overnight at $4{ }^{\circ} \mathrm{C}$. Secondary antibodies (HRP-conjugated) were added after three 5 min cycle wash steps with PBS-T and incubated with gentle rocking at $4{ }^{\circ} \mathrm{C}$ for $2 \mathrm{~h}$. Western blots were developed by Clarity Western ECL Substrate (BioRad) and ChemiDoc Molecular Imager Touch system (BioRad) was used to visualize and capture images. ImageJ software was used to obtain raw densitometry counts. Counts were normalized to background.

\section{Isolation of RNA, generation of CDNA, and real-time quantitative PCR (RT-qPCR)}

Whole cell lysates were used as sources of total RNA and later separated by Trizol-chloroform (MRC) per the manufacturer's instructions. Subsequently, specific reverse primers and GoScript Reverse Transcription System (Promega) were used to yield the corresponding cDNA from RNA isolates. Additionally, cDNA was also generated from purified total RNA obtained by NT086 nanotrap (Ceres Nanosciences Inc.) bound to virus. The 
following reserve primers were used: TAR Reverse: $\left(5^{\prime}-\right.$ CAA CAG ACG GGC ACA CAC TAC- $3^{\prime}, \mathrm{Tm}=58{ }^{\circ} \mathrm{C}$ ), Gag Reverse: (5'-GCT GGT AGG GCT ATA CAT TCT TAC- $3^{\prime} ; \mathrm{Tm}=54^{\circ} \mathrm{C}$ ), and OligoDT. Next, real time quantitative polymerase chain reaction (RT-qPCR) analysis was performed with $2 \mu \mathrm{L}$ of undiluted aliquots of cDNA using iQ supermix (BioRad) with primers specific for target TAR sequences: TAR-Reverse: (5'-CAA CAG ACG GGC ACA CAC TAC- $3^{\prime}, \mathrm{Tm}=58^{\circ} \mathrm{C}$ ) and TAR-Forward (5'-GGT CTC TCT GGT TAG ACC AGA TCT G-3', $\left.\mathrm{Tm}=60{ }^{\circ} \mathrm{C}\right)$; TAR-Probe $\left(5^{\prime}-/ 56\right.$-FAM/AGC CTC AAT AAA GCT TGC CTT GAG TGC TTC/36-TAMSp/-3'; $\left.\mathrm{Tm}=63.2{ }^{\circ} \mathrm{C}\right)$; GAPDH-Reverse $\left(5^{\prime}\right.$-CAG AGT TAA AAG CAG CCC TGG T- $3^{\prime}, \mathrm{Tm}=57.5^{\circ} \mathrm{C}$ ); GAPDH-Forward (5'-GAA GGT GAA GGT CGG AGT CAA C-3', $\left.\mathrm{Tm}=57.5^{\circ} \mathrm{C}\right)$; GAPDH-Probe $\left(5^{\prime}-/ 56\right.$-FAM/TTT GGT CGT ATT GGG CGC CT $/ 36$-TAMSp $/-3^{\prime}, \mathrm{Tm}=59.8^{\circ} \mathrm{C}$ ). For RT-qPCR of 7SK RNA, total RNA was isolated from fraction pull-downs with NT084 and generated corresponding cDNA with GoScript Reverse Transcription System (Promega, Madison, WI) using 7SK-RT reverse primer (5'-AAAAGAAAGGCAGACTGCC-3'). Relative RNA abundance (percent of peak) was quantitated by RT-qPCR using SYBR Green (BioRad, Hercules, CA) with the following pair of primers: 7SK-F (5'-GACA TCT GTCACCCCATTGA-3') and 7SK-R (5'-GCGCAGCTA CTCGTATACCC-3').

7SK RNA is shown as a percentage relative to the highest peak for each cell type. DNA from 8E5 cells (CEM T-cell line containing a single copy of HIV-1 LAV provirus per cell) was used as the quantitative standard after obtaining a concentration gradient by serial dilutions. The following PCR settings were used for TAR/TAR-gag: one cycle at $95{ }^{\circ} \mathrm{C}$ for $2 \mathrm{~min}, 41$ cycles at $95^{\circ} \mathrm{C}$ for $15 \mathrm{~s}$, and $60{ }^{\circ} \mathrm{C}$ or $50{ }^{\circ} \mathrm{C}$ (for respective primer sets) for $40 \mathrm{~s}$. PCR settings for 7SK RNA were the following: one cycle at $50{ }^{\circ} \mathrm{C}$ for $2 \mathrm{~min}$, followed by $95{ }^{\circ} \mathrm{C}$ for $2 \mathrm{~min}, 41$ cycles at $95{ }^{\circ} \mathrm{C}$ for $30 \mathrm{~s}, 65^{\circ} \mathrm{C}$ for $30 \mathrm{~s}$, and $72{ }^{\circ} \mathrm{C}$ for $30 \mathrm{~s}$. The limit of detection (LoD) was assessed by quantitation of background TAR-gag RNA copies detected in negative control (DiH20) and was determined to be 0 copies, also an indication of the specificity of our primer sequence. However, the limit of quantitation (LoQ) was established by our lowest concentration standard at $8 \times 10^{1}$ RNA copies of $8 \mathrm{E} 5$ cells. The cycle threshold $(\mathrm{Ct})$ value relative to the standard curve and used for absolute quantitation of samples. The BioRad CFX96 Real Time System was used for RT-qPCR. All RT-qPCR experiments were run in technical triplicates.

\section{Chromatin immunoprecipitation (ChIP)}

Cells were harvested and ChIP assay was performed with the Imprint Chromatin Immunoprecipitation Kit (Sigma) per the manufacturer's instructions. Briefly, samples were crosslinked, quenched, sonicated, and mono-disomes were used for immunoprecipitation. Appropriate antibodies were added, and the samples rotated overnight at $4{ }^{\circ} \mathrm{C}$. A $50 \%(\mathrm{v} / \mathrm{v})$ protein A-Sepharose/protein G-Sepharose mix was added, and the samples were rotated for $2 \mathrm{~h}$ at $4{ }^{\circ} \mathrm{C}$. The samples were washed two times with IP Wash Buffer (Sigma) before addition of Proteinase K (800 $\mathrm{U} / \mathrm{mL}$ ), then subsequently incubated for $15 \mathrm{~min}$ at $65^{\circ} \mathrm{C}$. Reversing solution (Sigma) was added and the samples were incubated at $65{ }^{\circ} \mathrm{C}$ for $90 \mathrm{~min}$. DNA was purified using elution columns and $\mathrm{qPCR}$ was performed with appropriate primers.

\section{Cell viability}

Cell viability was assessed by plating $5 \times 10^{4}$ cells (grown in fresh RPMI media and supplemented as described above) into a 96-well cell culture plate for 7 days, followed by treatment with Cas9+TAR3/6. Following a 5-day incubation, cells were treated with either DNA-PK inhibitor (NU 7441, SelleckChem, S2638), ATM inhibitor (KU 55933, SelleckChem, S1092), FAS antibody (Santa Cruz, sc-715), or a combination thereof. After 2 days, cell viability was tested using CellTiter-Glo Luminescent Cell Viability Assay (Promega). Luminescence was measured using the GloMax Multi-Detection System (Promega). All cell viability assays were conducted in biological triplicate and background signal was normalized with fresh RPMI media.

\section{Size-exclusion chromatography}

A transfection with Flag-Tat ${ }_{101}$ (a generous gift from Dr. Kuan-Teh Jeang at National Institutes of Health) was performed on HIV-1-infected (J1.1) and uninfected (Jurkat and CEM) cells at the early-mid log phase, and cells were then treated with F07\#13 for $48 \mathrm{~h}$. Pellets were then collected, washed with PBS, and lysed as described previously ("Effects of F07\#13 on various Tat complexes" section). Protein concentrations for supernatants were quantified via Bradford protein assay (BioRad) and $2.5 \mathrm{mg}$ of each sample was then equilibrated in $0.2 \mathrm{M}$ Tris- $\mathrm{HCl}$ (pH 7.5), $0.5 \mathrm{M} \mathrm{NaCl}$, and $5 \%$ glycerol. Samples underwent fast protein liquid chromatography (FPLC) (ÄKTA Purifier system; GE Healthcare Bio-Sciences) on a Superose 6 10/300 size-exclusion column (GE Healthcare BioScience). Separation between lower-molecular-weight complexes, eluting in higher fractions (far right-side of the column), and high-molecular-weight fractions, eluting in lower fractions (far left-side of the column), was improved by introducing a quarter-inch gap at the top of the Superose 6 column. Flow rate parameters for the FPLC were set at $0.3 \mathrm{~mL} / \mathrm{min}$ and $0.5 \mathrm{~mL}$ fractions of the flow-through were collected at $4{ }^{\circ} \mathrm{C}$ with approximately 
60 fractions per sample (1 $\mathrm{mL}$ injected). Nanotrap (NT084; Ceres Nanosciences Inc.) capture was used on every fifth fraction. Nanotrapped pellets were centrifuged at $4{ }^{\circ} \mathrm{C}$ for $10 \mathrm{~min}$ at $15,294 \times g$, supernatants were removed, and the pellets were allowed to dry for a few minutes at room temperature. The pellets were resuspended in Laemmli buffer and analyzed by immunoblotting for Tat as needed [a cocktail of HIV-1 Tat Monoclonal (4D5.24), HIV-1 Tat Monoclonal (7D5.1), HIV-1 Tat Monoclonal (5A5.3), and HIV-1 Tat (NT3 2D1.1) from Dr. Jonathan Karn, obtained through the AIDS Research and Reference Reagent Program, Division of AIDS, NIAID, NIH], cyclin T1 (Santa Cruz Biotechnology Inc., H-245), Cdk9 (Santa Cruz Biotechnology Inc., C-20), and $\beta$-actin (Abcam, AB49900). Additionally, every fifth fraction from J1.1 cells that were electroporated with Flag-Tat ${ }_{101}$ was screened for the elution of Tat using Flag M2 antibody.

\section{Immunoprecipitation}

Immunoprecipitation (IP) of RNA/protein complexes were performed by incubation of $0.5-1 \mathrm{~mL}$ of lysate fractions with $10 \mu \mathrm{g}$ of primary antibody overnight. The next day, a 30\% slurry of Protein A/G beads (Calbiochem) was added to the immunocomplexes and allowed to incubate for $2 \mathrm{~h}$ at $4{ }^{\circ} \mathrm{C}$. Samples were then washed twice with PBS and prepared for downstream assays. For the preparation of IP samples for RNA isolation, samples were resuspended in $50 \mu \mathrm{L}$ of PBS and subjected to RNA isolation for downstream RT-qPCR. In preparation for Western blot, resulting immunocomplexes were added to $10 \mu \mathrm{L}$ of Laemmli Buffer and subjected to the Western blot protocol described above.

\section{Generation of Cas9+TAR3/TAR6 vectors}

A generic sgRNA expression vector with a BsmBI cloning site was synthesized as gBLOCKs (IDT), which was amplified using a U6-F (5'-GAGGGCCTATTTCCCATG $-3^{\prime}$ ) and a tracrRNA-R primer (5'-ATAGCTTCCACC GCGGTGGCACGCGTAAAAAAGCACC GACTCG GTGCCACTTTTTCAAGTTGATAACGGACTAGC-3') with KAPA Taq Readymix (Roche Applied Science) and ligated into a pTZ57R/T vector using a InsTAclone PCR Cloning Kit (Thermo Scientific) according to the manufacturer instructions. To generate the TAR sgRNAs, the pTZ-U6-BsmBI-sgRNA backbone was prepared by digestion with BsmBI and the sgRNA target sequences were ligated into the vector using a standard complementary oligomer protocol (IDT). The pTZ-U6-BsmBI-sgRNA and pTZ-U6-sgRNAs TAR1-8 were confirmed using automated sequencing. The $s p$ Cas 9 expression vector was obtained from Addgene (px330, \#42230).

\section{Prediction of RNA secondary structure}

For prediction of the RNA secondary structures, the sequence of HIV-1 LTR and p17 region of gag DNA sequences were submitted to the Vienna RNA secondary structure server $[28,31]$. The server predicts the minimum free energy ( $m f e$ ) secondary structures for single RNA sequences/DNA sequences. The MFE structure of an RNA sequence is the secondary structure that contributes a minimum of free energy. This structure is predicted using a loop-based energy model and the dynamic programming algorithm introduced by Zuker et al. [78] This server also calculates the full equilibrium partition function for secondary structure and the probabilities of various substructures by using partition function ( $p f)$ algorithm proposed by McCaskill [49]. All the secondary structure predictions were performed for a temperature of $37^{\circ} \mathrm{C}$, keeping all the other parameters to default [46].

\section{Statistical analysis}

Standard deviations (SD) were calculated using Microsoft Excel for every quantitative experiment. Two-tailed student's $t$-test were performed to obtain $p$-values to determine statistical significance. Values could be considered statistically significant $(p<0.05)$, of greater significance $(p<0.01)$, and of greatest significance $(p<0.001)$.

\section{Additional file}

Additional file 1. Supplementary Data.

\begin{abstract}
Abbreviations
AIDS: acquired immunodeficiency syndrome; CART: combination antiretroviral therapy; Cas9: CRISPR associated protein 9; Cdk: cyclin dependent kinase; ChIP: chromatin immunoprecipitation; CMV: cytomegalovirus; CRISPR: clustered regularly interspaced short palindromic repeats; DMA: dimethylacetamide; FPLC: fast protein liquid chromatography; gRNA: guide RNA; HAND: HIV-1 associated neurocognitive disorder; HIV-1: human immunodeficiency virus 1; i.p.: intraperitoneal; IFN-ү: interferon-gamma; IP: immunoprecipitation; IR: ionizing radiation; IncRNAs: long non-coding RNA; LoD: limit of detection; LoQ: limit of quantitation; LTR: long terminal repeat; miRNA: micro RNA; ncRNA: non-coding RNA; nuc: Nucleosome; P-TEFb: positive transcription elongation factor b; PBS-T: PBS-Tween 20; PBS: phosphate-buffered saline; PD: pharmacodynamics; PEG: polyethylene glycol 400; PHA: phytohemagglutinin P; PK: pharmacokinetics; PMA: phorbol 12-myristate 13-acetate; Pol II: RNA polymerase II; RT-qPCR: real-time quantitative polymerase chain reaction; SEC: super elongation complex; snRNA: small nuclear RNA; TAR: transactivating response element; TCR:T cell receptor; TGS: transcriptional gene silencing; Ub: ubiquitinated.
\end{abstract}

\section{Authors' contributions}

DOP, CD, MLP, TTV, MS, JE, MC, and RAB, carried out most of the experiments, contributed to cell culture work, RNA isolation, RT-qPCR, Western blots, ChIP assays, FPLC, and data analysis. All CRISPR experiments were performed by TAS and MSW. DK and CZ contributed to experimental designs, evaluation and reevaluation of RNA structures for TAR-gag and PRC2. FK contributed to the overall direction and coordination of the study as well as to experimental design and data interpretation. All authors read and approved the final manuscript. 


\begin{abstract}
Author details
${ }^{1}$ Laboratory of Molecular Virology, School of Systems Biology, George Mason University, Manassas, VA, USA. ${ }^{2}$ Center for Gene Therapy, Beckman Research Institute of City of Hope, Duarte, CA, USA. ${ }^{3}$ Protein Engineering Department, Institute of Molecular Biology and Genetics, UAS, Kiev, Ukraine. ${ }^{4}$ Department of Physics, The George Washington University, Washington, DC, USA. ${ }^{5}$ Department of Molecular and Experimental Medicine, The Scripps Research Institute, La Jolla, CA, USA. ${ }^{6}$ Wits/SA MRC Antiviral Gene Therapy Research Unit, Department of Molecular Medicine and Haematology, University of the Witwatersrand, Johannesburg, South Africa. ${ }^{7}$ Laboratory of Molecular Virology, George Mason University, Discovery Hall Room 182, 10900 University Blvd., Manassas, VA 20110, USA.
\end{abstract}

\section{Acknowledgements}

We would like to thank Kevin V. Morris for his guidance during CRISPR experimental designs, Pooja Khatkar for her help generating the RNA structures in the supplementary data, and Yuriy Kim, Gwen Cox, and all members of the Kashanchi lab for their support.

\section{Competing interests}

Authors declare no potential conflicts of interest. The content is solely the responsibility of the authors and does not necessarily represent the official views of the National Institutes of Health.

\section{Availability of data and materials}

The data for this study is available from the corresponding author on reasonable request.

\section{Consent for publication}

Not applicable.

Ethics approval and consent to participate

Not applicable.

\section{Funding}

This research study was supported by NIH Grant AI078859, Al074410, and Al043894 and R01MH110262 to FK.

\section{Publisher's Note}

Springer Nature remains neutral with regard to jurisdictional claims in published maps and institutional affiliations.

Received: 30 June 2018 Accepted: 20 April 2019

Published online: 29 April 2019

\section{References}

1. Akpamagbo YA, DeMarino C, Pleet ML, Schwab A, Rodriguez M, Barclay RA, Sampey G, lordanskiy S, El-Hage N, Kashanchi F. HIV-1 transcription inhibitors increase the synthesis of viral non-coding RNA that contribute to latency. Curr Pharm Des. 2017;23:4133-44. https://doi. org/10.2174/1381612823666170622101319.

2. Ali A, Raja R, Farooqui SR, Ahmad S, Banerjea AC. USP7 deubiquitinase controls HIV-1 production by stabilizing Tat protein. Biochem J. 2017;474:1653-68. https://doi.org/10.1042/BCJ20160304.

3. Ammosova T, Berro R, Jerebtsova M, Jackson A, Charles S, Klase Z, Southerland W, Gordeuk VR, Kashanchi F, Nekhai S. Phosphorylation of HIV-1 Tat by CDK2 in HIV-1 transcription. Retrovirology. 2006;3:78. https://doi. org/10.1186/1742-4690-3-78.

4. Angelov D, Charra M, Seve M, Côté J, Khochbin S, Dimitrov S. Differential remodeling of the HIV-1 nucleosome upon transcription activators and SWI/SNF complex binding. J Mol Biol. 2000;302:315-26. https://doi. org/10.1006/jmbi.2000.4069.

5. Archin NM, Sung JM, Garrido C, Soriano-Sarabia N, Margolis DM. Eradicating HIV-1 infection: seeking to clear a persistent pathogen. Nat Rev Microbiol. 2014;12:750-64. https://doi.org/10.1038/nrmicro3352.

6. Asamitsu K, Fujinaga K, Okamoto T. HIV Tat/P-TEFb interaction: a potential target for novel anti-HIV therapies. Molecules. 2018. https://doi. org/10.3390/molecules23040933.
7. Barclay RA, Schwab A, DeMarino C, Akpamagbo Y, Lepene B, Kassaye S, lordanskiy S, Kashanchi F. Exosomes from uninfected cells activate transcription of latent HIV-1. J Biol Chem. 2017;292:14764. https://doi. org/10.1074/jbc.A117.793521.

8. Bisgrove DA, Mahmoudi T, Henklein P, Verdin E. Conserved P-TEFb-interacting domain of BRD4 inhibits HIV transcription. Proc Natl Acad Sci USA. 2007;104:13690-5. https://doi.org/10.1073/pnas.0705053104.

9. Bosque A, Nilson KA, Macedo AB, Spivak AM, Archin NM, Van Wagoner RM, Martins LJ, Novis CL, Szaniawski MA, Ireland CM, Margolis DM, Price DH, Planelles V. Benzotriazoles reactivate latent HIV-1 through inactivation of STAT5 SUMOylation. Cell Rep. 2017;18:1324-34. https://doi. org/10.1016/j.celrep.2017.01.022.

10. Budhiraja S, Rice AP. Reactivation of latent HIV: do all roads go through P-TEFb? Future Virol. 2013. https://doi.org/10.2217/fvl.13.52.

11. Canduri F, Perez PC, Caceres RA, de Azevedo WF. CDK9 a potential target for drug development. Med Chem. 2008;4:210-8.

12. Carpio L, Klase Z, Coley W, Guendel I, Choi S, Van Duyne R, Narayanan A, Kehn-Hall K, Meijer L, Kashanchi F. microRNA machinery is an integral component of drug-induced transcription inhibition in HIV-1 infection. J RNAi Gene Silencing. 2010:6:386-400.

13. Chen Shiyou, Yang X, Cheng W, Ma Y, Shang Y, Cao L, Chen Shuliang, Chen Y, Wang M, Guo D. Immune regulator ABIN1 suppresses HIV-1 transcription by negatively regulating the ubiquitination of Tat. Retrovirology. 2017;14:12. https://doi.org/10.1186/s12977-017-0338-5.

14. Chou S, Upton H, Bao K, Schulze-Gahmen U, Samelson AJ, He N, Nowak A, Lu H, Krogan NJ, Zhou Q, Alber T. HIV-1 Tat recruits transcription elongation factors dispersed along a flexible AFF4 scaffold. Proc Natl Acad Sci USA. 2013;110:E123-31. https://doi.org/10.1073/pnas.1216971110.

15. Cobanoglu G, Turacli ID, Ozkan AC, Ekmekci A. Flavopiridol's antiproliferative effects in glioblastoma multiforme. J Cancer Res Ther. 2016;12:811-7. https://doi.org/10.4103/0973-1482.172132.

16. Dassouki Z, Sahin U, Hajj HE, Jollivet F, Kfoury Y, Lallemand-Breitenbach $V$, Hermine $O$, de Thé $H$, Bazarbachi A. ATL response to arsenic/interferon therapy is triggered by SUMO/PML/RNF4-dependent Tax degradation. Blood. 2015;125:474-82. https://doi.org/10.1182/blood-2014-04-572750.

17. Davidovich C, Cech TR. The recruitment of chromatin modifiers by long noncoding RNAs: lessons from PRC2. RNA. 2015;21:2007-22. https://doi. org/10.1261/rna.053918.115.

18. DeMarino C, Pleet ML, Cowen M, Barclay RA, Akpamagbo Y, Erickson J, Ndembe N, Charurat M, Jumare J, Bwala S, Alabi P, Hogan M, Gupta A Hooten NN, Evans MK, Lepene B, Zhou W, Caputi M, Romerio F, Royal W, El-Hage N, Liotta LA, Kashanchi F. Antiretroviral drugs alter the content of extracellular vesicles from HIV-1-infected cells. Sci Rep. 2018. https://doi. org/10.1038/s41598-018-25943-2.

19. Deng L, de la Fuente C, Fu P, Wang L, Donnelly R, Wade JD, Lambert P, Li H, Lee CG, Kashanchi F. Acetylation of HIV-1 Tat by CBP/P300 increases transcription of integrated HIV-1 genome and enhances binding to core histones. Virology. 2000;277:278-95. https://doi.org/10.1006/ viro.2000.0593.

20. Di Santo R. Inhibiting the HIV integration process: past, present, and the future. J Med Chem. 2014;57:539-66. https://doi.org/10.1021/jm400674a.

21. Ding J, Miao Z-H, Meng L-H, Geng M-Y. Emerging cancer therapeutic opportunities target DNA-repair systems. Trends Pharmacol Sci Spec Issue China. 2006;27:338-44. https://doi.org/10.1016/j.tips.2006.04.007.

22. Easley R, Carpio L, Dannenberg L, Choi S, Alani D, Van Duyne R, Guendel I, Klase Z, Agbottah E, Kehn-Hall K, Kashanchi F. Transcription through the HIV-1 nucleosomes: effects of the PBAF complex in Tat activated transcription. Virology. 2010;405:322-33. https://doi.org/10.1016/j.virol 2010.06.009.

23. Farhadian S, Patel P, Spudich S. Neurological complications of HIV infection. Curr Infect Dis Rep. 2017;19:50. https://doi.org/10.1007/s1190 8-017-0606-5.

24. Friedman J, Cho W-K, Chu CK, Keedy KS, Archin NM, Margolis DM, Karn J. Epigenetic silencing of HIV-1 by the histone H3 lysine 27 methyltransferase enhancer of Zeste 2. J Virol. 2011;85:9078-89. https://doi. org/10.1128/JVI.00836-11.

25. Gasiunas G, Barrangou R, Horvath P, Siksnys V. Cas9-crRNA ribonucleoprotein complex mediates specific DNA cleavage for adaptive immunity in bacteria. PNAS. 2012;109:15539-40. 
26. Gelman BB. Neuropathology of HAND with suppressive antiretroviral therapy: encephalitis and neurodegeneration reconsidered. Curr HIV/ AIDS Rep. 2015;12:272-9. https://doi.org/10.1007/s11904-015-0266-8.

27. Global AIDS Update 2016. UNAIDS; 2016.

28. Gruber AR, Lorenz R, Bernhart SH, Neuböck R, Hofacker IL. The Vienna RNA websuite. Nucleic Acids Res. 2008;36:W70-4. https://doi. org/10.1093/nar/gkn188.

29. Guo L, Liu X, Jiang Y, Nishikawa K, Plunkett W. DNA-dependent protein kinase and ataxia telangiectasia mutated (ATM) promote cell survival in response to NK314, a topoisomerase lla inhibitor. Mol Pharmacol. 2011:80:321-7. https://doi.org/10.1124/mol.109.057125.

30. Heaton RK, Clifford DB, Franklin DR, Woods SP, Ake C, Vaida F, Ellis RJ, Letendre SL, Marcotte TD, Atkinson JH, Rivera-Mindt M, Vigil OR, Taylor MJ, Collier AC, Marra CM, Gelman BB, McArthur JC, Morgello S, Simpson DM, McCutchan JA, Abramson I, Gamst A, Fennema-Notestine C, Jernigan TL, Wong J, Grant I, CHARTER Group. HIV-associated neurocognitive disorders persist in the era of potent antiretroviral therapy: CHARTER Study. Neurology. 2010;75:2087-96. https://doi.org/10.1212/WNL.0b013e3182 $00 \mathrm{~d} 727$.

31. Hofacker IL. Vienna RNA secondary structure server. Nucleic Acids Res. 2003;31:3429-31.

32. Holec AD, Mandal S, Prathipati PK, Destache CJ. Nucleotide reverse transcriptase inhibitors: a thorough review, present status and future perspective as HIV therapeutics. Curr HIV Res. 2017;15:411-21. https://doi. org/10.2174/1570162X15666171120110145.

33. Hong H-W, Lee S-W, Myung H. Induced degradation of Tat by nucleocapsid (NC) via the proteasome pathway and its effect on HIV transcription. Viruses. 2013;5:1143-52. https://doi.org/10.3390/v5041143.

34. Hope TJ, Richman D, Stevenson M, editors. Encyclopedia of AIDS. New York: Springer; 2018.

35. Hughes PJ, Cretton-Scott E, Teague A, Wensel TM. Protease inhibitors for patients with HIV-1 infection. P T. 2011;36:332-45.

36. Jadlowsky JK, Wong JY, Graham AC, Dobrowolski C, Devor RL, Adams $M D$, Fujinaga K, Karn J. Negative elongation factor is required for the maintenance of proviral latency but does not induce promoter-proximal pausing of RNA polymerase II on the HIV long terminal repeat. Mol Cell Biol. 2014;34:1911-28. https://doi.org/10.1128/MCB.01013-13.

37. Jaworski E, Saifuddin M, Sampey G, Shafagati N, Van Duyne R, lordanskiy S, Kehn-Hall K, Liotta L, Petricoin E, Young M, Lepene B, Kashanchi F. The use of nanotrap particles technology in capturing HIV-1 virions and viral proteins from infected cells. PLoS ONE. 2014. https://doi.org/10.1371/ journal.pone.0096778.

38. Kim YK, Mbonye U, Hokello J, Karn J. T-cell receptor signaling enhances transcriptional elongation from latent HIV proviruses by activating P-TEFb through an ERK-dependent pathway. J Mol Biol. 2011;410:896-916. https ://doi.org/10.1016/j.jmb.2011.03.054.

39. Klase Z, Kale P, Winograd R, Gupta MV, Heydarian M, Berro R, McCaffrey T, Kashanchi F. HIV-1 TAR element is processed by Dicer to yield a viral micro-RNA involved in chromatin remodeling of the viral LTR. BMC Mol Biol. 2007;8:63. https://doi.org/10.1186/1471-2199-8-63.

40. Krueger BJ, Varzavand K, Cooper JJ, Price DH. The mechanism of release of P-TEFb and HEXIM1 from the 7SK snRNP by viral and cellular activators includes a conformational change in 7SK. PLoS ONE. 2010;5:e12335. https ://doi.org/10.1371/journal.pone.0012335.

41. Kumar A, Abbas W, Herbein G. HIV-1 latency in monocytes/macrophages. Viruses. 2014;6:1837-60. https://doi.org/10.3390/v6041837.

42. Kuzmina A, Krasnopolsky S, Taube R. Super elongation complex promotes early HIV transcription and its function is modulated by P-TEFb. Transcription. 2017:8:133-49. https://doi.org/10.1080/21541264.2017.1295831.

43. Li J, Chen C, Ma X, Geng G, Liu B, Zhang Y, Zhang S, Zhong F, Liu C, Yin $Y$, Cai W, Zhang H. Long noncoding RNA NRON contributes to HIV-1 latency by specifically inducing tat protein degradation. Nat Commun. 2016;7:11730. https://doi.org/10.1038/ncomms11730.

44. Lu L, Yu F, Cai L, Debnath AK, Jiang S. Development of small-molecule HIV entry inhibitors specifically targeting gp120 or gp41. Curr Top Med Chem. 2016;16:1074-90.

45. Mahmoudi T. The BAF complex and HIV latency. Transcription. 2012;3:171-6. https://doi.org/10.4161/trns.20541.

46. Mathews DH, Sabina J, Zuker M, Turner DH. Expanded sequence dependence of thermodynamic parameters improves prediction of RNA secondary structure. J Mol Biol. 1999;288:911-40. https://doi.org/10.1006/ jmbi.1999.2700.

47. Mbonye $U$, Karn J. The molecular basis for human immunodeficiency virus latency. Annu Rev Virol. 2017;4:261-85. https://doi.org/10.1146/ annurev-virology-101416-041646.

48. Mbonye U, Karn J. Transcriptional control of HIV latency: cellular signaling pathways, epigenetics, happenstance and the hope for a cure. Virology. 2014;454-455:328-39. https://doi.org/10.1016/j.virol.2014.02.008.

49. McCaskill JS. The equilibrium partition function and base pair binding probabilities for RNA secondary structure. Biopolymers. 1990;29:1105-19. https://doi.org/10.1002/bip.360290621.

50. McFadden EJ, Hargrove AE. Biochemical methods to investigate IncRNA and the influence of IncRNA: protein complexes on chromatin. Biochemistry. 2016;55:1615-30. https://doi.org/10.1021/acs.biochem.5b01141.

51. Mendonça LM, Poeys SC, Abreu CM, Tanuri A, Costa LJ. HIV-1 nef inhibits protease activity and its absence alters protein content of mature viral particles. PLoS ONE 2014;9:e95352. https://doi.org/10.1371/journ al.pone.0095352.

52. Mingyan Y, Xinyong L, De Clercq E. NF-kappaB: the inducible factors of HIV-1 transcription and their inhibitors. Mini Rev Med Chem. 2009;9:60-9.

53. Narayanan A, Sampey G, Van Duyne R, Guendel I, Kehn-Hall K, Roman J, Currer R, Galons H, Oumata N, Joseph B, Meijer L, Caputi M, Nekhai S, Kashanchi F. Use of ATP analogs to inhibit HIV-1 transcription. Virology. 2012;432:219-31. https://doi.org/10.1016/j.virol.2012.06.007.

54. Pagans S, Kauder SE, Kaehlcke K, Sakane N, Schroeder S, Dormeyer W, Trievel RC, Verdin E, Schnolzer M, Ott M. The cellular lysine methyltransferase Set7/9-KMT7 binds HIV-1 TAR RNA, monomethylates the viral transactivator Tat, and enhances HIV transcription. Cell Host Microbe. 2010;7:234-44. https://doi.org/10.1016/j.chom.2010.02.005.

55. Pazhouhandeh M, Molinier J, Berr A, Genschik P. MSI4/FVE interacts with CUL4-DDB1 and a PRC2-like complex to control epigenetic regulation of flowering time in Arabidopsis. Proc Natl Acad Sci USA. 2011;108:3430-5. https://doi.org/10.1073/pnas.1018242108.

56. Perreau M, Banga R, Pantaleo G. Targeted immune interventions for an HIV-1 cure. Trends Mol Med. 2017;23:945-61. https://doi.org/10.1016/j. molmed.2017.08.006.

57. Pumfery A, de la Fuente C, Berro R, Nekhai S, Kashanchi F, Chao S-H. Potential use of pharmacological cyclin-dependent kinase inhibitors as anti-HIV therapeutics. Curr Pharm Des. 2006;12:1949-61.

58. Quivy V, De Walque S, Van Lint C. Chromatin-associated regulation of HIV-1 transcription: implications for the development of therapeutic strategies. Subcell Biochem. 2007:41:371-96.

59. Rafati H, Parra M, Hakre S, Moshkin Y, Verdin E, Mahmoudi T. Repressive LTR nucleosome positioning by the BAF complex is required for HIV latency. PLoS Biol. 2011;9:e1001206. https://doi.org/10.1371/journ al.pbio. 1001206.

60. Rao KS, Ghorpade A, Labhasetwar V. Targeting anti-HIV drugs to the CNS. Expert Opin Drug Deliv. 2009;6:771-84. https://doi.org/10.1517/17425 240903081705.

61. Roman A, Munger K. The papillomavirus E7 proteins. Virology. 2013;445:138-68. https://doi.org/10.1016/j.virol.2013.04.013.

62. Saayman S, Ackley A, Turner A-MW, Famiglietti M, Bosque A, Clemson M, Planelles V, Morris KV. An HIV-encoded antisense long noncoding RNA epigenetically regulates viral transcription. Mol Ther. 2014;22:1164-175. https://doi.org/10.1038/mt.2014.29.

63. Shan L, Yang H-C, Rabi SA, Bravo HC, Shroff NS, Irizarry RA, Zhang H, Margolick JB, Siliciano JD, Siliciano RF. Influence of host gene transcription level and orientation on HIV-1 latency in a primary-cell model $\nabla$. J Virol. 2011;85:5384-93. https://doi.org/10.1128/JVI.02536-10.

64. Sharifi HJ, Furuya AM, de Noronha CMC. The role of HIV-1 Vpr in promoting the infection of nondividing cells and in cell cycle arrest. Curr Opin HIV AIDS. 2012;7:187-94. https://doi.org/10.1097/COH.0b013e32835049e 0 .

65. Solomon DA, Sax PE. Current state and limitations of daily oral therapy for treatment. Curr Opin HIV AIDS. 2015;10:219-25. https://doi.org/10.1097/ $\mathrm{COH} .0000000000000165$.

66. Srikumar T, Padmanabhan J. Potential use of flavopiridol in treatment of chronic diseases. Adv Exp Med Biol. 2016;929:209-28. https://doi. org/10.1007/978-3-319-41342-6_9. 
67. Tripathy MK, Abbas W, Herbein G. Epigenetic regulation of HIV-1 transcription. Epigenomics. 2011;3:487-502. https://doi.org/10.2217/ epi.11.61.

68. Van Duyne R, Cardenas J, Easley R, Wu W, Kehn-Hall K, Klase Z, Mendez S, Zeng C, Chen H, Saifuddin M, Kashanchi F. Effect of transcription peptide inhibitors on HIV-1 replication. Virology. 2008;376:308-22. https://doi. org/10.1016/j.virol.2008.02.036.

69. Van Duyne R, Guendel I, Jaworski E, Sampey G, Klase Z, Chen H, Zeng C, Kovalskyy D, el Kouni MH, Lepene B, Patanarut A, Nekhai S, Price $\mathrm{DH}$, Kashanchi F. Effect of mimetic CDK9 inhibitors on HIV-1 activated transcription. J Mol Biol. 2013;425:812-29. https://doi.org/10.1016/j. jmb.2012.12.005.

70. Van Duyne R, Kehn-Hall K, Carpio L, Kashanchi F. Cell-type-specific proteome and interactome: using HIV-1 Tat as a test case. Expert Rev Proteom. 2009;6:515-26. https://doi.org/10.1586/epr.09.73.

71. Van Lint C, Bouchat S, Marcello A. HIV-1 transcription and latency: an update. Retrovirology. 2013;10:67. https://doi. org/10.1186/1742-4690-10-67.

72. Verdin E, Paras P, Van Lint C. Chromatin disruption in the promoter of human immunodeficiency virus type 1 during transcriptional activation. EMBO J. 1993;12:3249-59.

73. Wang C, Long W, Peng C, Hu L, Zhang Q, Wu A, Zhang X, Duan X, Wong CCL, Tanaka Y, Xia Z. HTLV-1 Tax functions as a ubiquitin E3 ligase for direct IKK activation via synthesis of mixed-linkage polyubiquitin chains. PLoS Pathog. 2016;12:e1005584. https://doi.org/10.1371/journ al.ppat.1005584.

74. Wires ES, Alvarez D, Dobrowolski C, Wang Y, Morales M, Karn J, Harvey BK. Methamphetamine activates nuclear factor kappa-light-chain-enhancer of activated B cells (NF-KB) and induces human immunodeficiency virus (HIV) transcription in human microglial cells. J Neurovirol. 2012;18:40010. https://doi.org/10.1007/s13365-012-0103-4.

75. Wu L, Zhang $L$, Zheng S. Role of the long non-coding RNA HOTAIR in hepatocellular carcinoma. Oncol Lett. 2017;14:1233-9. https://doi. org/10.3892/ol.2017.6312

76. Yu X, Ai J, Cai L, Jing Y, Wang D, Dong J, Pascal LE, Zhang J, Luo R, Wang Z. Regulation of tumor suppressor EAF2 polyubiquitination by ELL1 and SIAH2 in prostate cancer cells. Oncotarget. 2016;7:29245-54. https://doi. org/10.18632/oncotarget.8588.

77. Zhang JL, Crumpacker C. Eradication of HIV and cure of AIDS, now and how? Front Immunol. 2013. https://doi.org/10.3389/fimmu.2013.00337.

78. Zuker M, Stiegler P. Optimal computer folding of large RNA sequences using thermodynamics and auxiliary information. Nucleic Acids Res. 1981:9:133-48.
Ready to submit your research? Choose BMC and benefit from:

- fast, convenient online submission

- thorough peer review by experienced researchers in your field

- rapid publication on acceptance

- support for research data, including large and complex data types

- gold Open Access which fosters wider collaboration and increased citations

- maximum visibility for your research: over 100M website views per year

At BMC, research is always in progress.

Learn more biomedcentral.com/submissions 